This is the post-print version of the following article:

Gistri, G., Corciolani, M., Pace, S. (2019) "Does the perception of incongruence hurt more? Customers' responses to CSR crises affecting the main reputation dimension of a company", Journal of Marketing Management, 35, 7-8, 605-633, ISSN 0267-257X, DOI

10.1080/0267257X.2019.1580761 (Available online 11 March 2019).

The final publication is available at:

https://www.tandfonline.com/doi/abs/10.1080/0267257X.2019.1580761 


\title{
Does the perception of incongruence hurt more? Customers' responses to CSR crises affecting the main reputation dimension of a company
}

\author{
Giacomo Gistri (corresponding author)
}

Department of Political Sciences, Communication and International Relations, University of Macerata, Macerata, Italy

Via Don Minzoni, 22a - 62100 Macerata (Italy)

Voice: +3907332582557

giacomo.gistri@unimc.it

https://orcid.org/0000-0003-2988-9758

Giacomo Gistri, PhD, is Associate Professor of Marketing at the Department of Political Sciences, Communication and International Relations, University of Macerata (Italy). He obtained his PhD in Business Administration at the University of Parma (Italy). He has been a Visiting Research Scholar at Southern Illinois University at Carbondale. His research interests include consumer behavior and marketing communications. He has published in academic journals, including the International Journal of Advertising, Marketing Letters, Journal of Marketing Communication, Journal of Cleaner Production and Journal of Brand Management.

\section{Matteo Corciolani}

Department of Economics and Management, University of Pisa, Pisa, Italy

Matteo Corciolani, $\mathrm{PhD}$, is an Associate Professor at the Department of Economics and Management, University of Pisa (Italy). He has a PhD in Business Administration from the University of Pisa. He teaches Consumer Behavior and Marketing Communications, and his research interests focus mainly on consumer behavior. His projects include the consumption of authentic items, consumption communities, cause-related marketing, and crisis management. $\mathrm{He}$ has published in the International Journal of Market Research, Management Decision, Journal of Cleaner Production and Marketing Theory.

\section{Stefano Pace}

Department of Marketing, Kedge Business School, Marseille, France 
Stefano Pace, $\mathrm{PhD}$, is Associate Professor in Consumer Behavior and Marketing at Kedge Business School (Marseille, France). He obtained his PhD in Business Administration \& Management at Bocconi University (Milan, Italy), where he has been the Director of the Master in Marketing \& Communication and currently teaches courses in consumer behavior. He has been a visiting $\mathrm{PhD}$ student at the Wharton Business School (Philadelphia, PA) and visiting scholar at the University of Bath (School of Management) and the Karlstad University (CTF, Service Research Center; Sweden). His research interests mainly relate to consumer behavior in the online and offline domains. His publications include articles in international peer-reviewed journals, such as Organization, Journal of Business Ethics, Marketing Theory, Marketing Letters, International Marketing Review, European Journal of Marketing, Journal of Cleaner Production and Group Decision and Negotiation. 


\title{
Does the perception of incongruence hurt more? Customers' responses to CSR crises affecting the main reputation dimension of a company
}

\author{
Corporate social responsibility (CSR) generates benefits for companies and \\ society. However, CSR exposes a company to potential damage when a critical \\ event, such as a crisis, disconfirms the CSR of a corporate reputation. The present \\ article introduces to the crisis management literature the notion of consumer- \\ perceived incongruence (CPI) between corporate reputation and crises. Our first \\ experimental study demonstrates that a high CPI - compared to a low CPI - \\ worsens consumer responses in terms of attitude toward the corporation (ATC), \\ word of mouth (WOM), and purchase intention (PI). The second study shows that \\ these effects are mediated by the perception of a state of discomfort on the part of \\ the consumer. The third study suggests that, in cases of high CPI, the corporate \\ crisis response strategy of apology outperforms that of compensation in reducing \\ the negative effects of discomfort on consumer responses. Theoretical and \\ managerial implications are discussed.
}

Summary statement of contribution

We contribute to the literature on CSR crises by unbundling the relationship between crises and CSR reputation. Specifically, we investigate whether crises impacting different dimensions of the CSR can elicit different reactions on the part of consumers. Notably, we show that effects on consumers differ depending on whether a crisis matches the CSR dimension for which the company is considered reputable.

Keywords: CSR; corporate reputation; crisis management; incongruence; apology; compensation; consumer behavior

\section{Introduction}

Corporate social responsibility (CSR) is an established feature of the strategies of most companies and is a key component of corporate reputation (Hetze, 2016). According to PricewaterhouseCoopers' 19th annual Global CEO Survey (2016), 64\% of CEOs said that "CSR is core to their business rather than being a stand-alone program" because it helps build trust with consumers, partners, governments, and their employees. ${ }^{i}$ CSR 
initiatives also impact the demand side (Ingenbleek, Meulenberg, \& Van Trijp, 2015). According to the Nielsen Global Survey on CSR (2015), most customers are willing to pay extra for products and services from companies committed to social and environmental issues.

The growing relevance of CSR for companies and customers indicates that a company could invest in CSR to improve its reputation (e.g., Janssen et al., 2015; Smith, 2013). However, this investment might also increase the vulnerability of the company itself (Coombs \& Holladay, 2015). In 2015, for example, Amazon occupied first place in terms of reputation considering "workplace experience" in the United States ranking (Reputation Institute, 2015). However, when the New York Times published the results of its investigation highlighting the "negative" conditions shared by Amazon employees,${ }^{\text {ii }}$ the company experienced a relevant setback on its reputational capital inside the United States and abroad. In fact, according to the Global CSR RepTrak ranking 2016 (Reputation Institute, 2016), Amazon's global CSR reputation dropped from the 29th to the 62 nd position within only a year.

As the example of Amazon shows, the role of CSR in times of crisis can be multifaceted and might not always be the insurance policy against crises that it is expected or hoped to be. CSR, in fact, can be a source of crisis risk, not just an asset used to protect a company's reputation during a crisis (Coombs \& Holladay, 2015). In this regard, previous studies have indicated that CSR can both help establish a pre-crisis reputation (e.g., Varadarajan \& Menon, 1988) and be part of a post-crisis response strategy (e.g., Vanhamme \& Grobben, 2009). To our knowledge, however, the literature has not sufficiently explored the relationship between CSR reputation and CSR crisis. Specifically, we argue that it is important to better investigate their interaction and the consequent impacts on consumer reactions because depending on whether a crisis 
affects the same CSR dimension of a good corporate reputation or some other dimension, it can differently affect consumer reactions toward the company. More specifically, we aim to answer the following research questions: What happens if a company that it is well reputed for a particular reason (e.g., its excellent workplace environment) is involved in a scandal related to the same reason (e.g., it is accused of treating its workers unfairly)? Would it be different if the scandal concerned other CSR dimensions? What kind of corporate post-crisis response strategy is best for reducing related damages?

To answer to these questions, we believe it is important to introduce the concept of consumer perception of incongruence (CPI) to the crisis management literature. Indeed, a crisis involving a well-reputed organization seems to trigger the perception of incongruence on the part of stakeholders, who must confront information with a different valence (Janssen et al., 2015; Zavyalova, Pfarrer, Reger, \& Hubbard, 2016). On the one hand, they know that the company has a good corporate reputation. On the other hand, they note that the same company is involved in a critical event, which disconfirms its reputation and places its activity into question. In this regard, we argue that, in cases of dimensional matches between the CSR dimension for which a corporation has a good reputation and the event triggering a crisis, the CPI can be higher than in cases of mismatches. For instance, the same environmental incident would harm a company recognized for being responsive to ecological issues (i.e., high CPI) significantly more than a company acknowledged for its employment policies (i.e., low CPI). Across three experimental studies, we thus demonstrate that, compared to a case of low CPI, a case of high CPI generates more intense damage to the company in terms of consumer attitude toward the corporation (ATC), word of mouth (WOM), and purchase intention (PI). 
We then identify a state of discomfort as one psychological mechanism that explains why, compared to a low level of CPI, a high level of CPI determines worse consumer reactions. Considering the situational crisis communication theory (Coombs, 2007), we finally illustrate how alternative corporate post-crisis communication strategies work in attenuating the negative impact of discomfort on consumer reactions toward the company.

\section{Conceptual framework}

\section{Relationship among corporate reputation, crises, and CSR}

Corporate reputation can be viewed as the accumulated impressions that stakeholders form about a company, resulting from interactions with the company itself and the communication received about it (Chun, 2005). The overall reputation cumulates different stakeholders' perceptions and directly affects the manner in which stakeholders behave toward an organization, generating a variety of positive effects for the company (Deephouse \& Carter, 2005; Grund \& Fombrun, 1996; Rao, 1994; Rindova, Williamson, Petkova, \& Sever, 2005). The extant research has extensively investigated the role of a good reputation in cases of negative events (Bundy, Pfarrer, Short, \& Coombs, 2016; Zavyalova et al., 2016). Nonetheless, the literature analysing the effects of an organization's reputation on stakeholders' perceptions and reactions to negative events has been inconclusive (Zavyalova et al., 2016). For instance, certain studies have found that the social capital and goodwill of a well-reputed organization can attenuate the adverse effects of a negative event on stakeholders' perceptions of the organization and support for it. Following this stream of research, Caruana (1997) concluded that a favourable reputation creates a halo effect that protects the organization. Similarly, Klein and Dawar (2004) and Eisingerich et al. (2011) suggested 
that CSR provides companies with some protection against crises, implying that ex ante CSR communication might buffer the magnitude of a decrease in consumers' attitudes. In contrast, other authors have found alternative results; that is, a good reputation has been deemed able to amplify the adverse effects of a negative event (e.g., Coombs \& Holladay, 2002, 2006). There are two primary mechanisms associated with these findings. First, negative events in high-reputation organizations are typically perceived as more salient than in organizations without this asset. In fact, negative news about companies that significantly invest in CSR tend to capture people's attention to a greater extent than crises involving companies with no CSR visibility (Janssen et al., 2015). As a result, these negative events attract more negative attention from stakeholders (Rhee \& Haunschild, 2006).

Second, negative events in high-reputation organizations are associated with a greater violation of expectations compared to similar events in other organizations (Burgoon, 1993; Rhee \& Haunschild, 2006). This effect is particularly true for organizations with good reputations in CSR (Sohn \& Lariscy, 2015). In fact, Jeon and Baeck (2016) found that consumers' responses are less adverse in corporate abilities crises than in CSR crises. Coombs and Holladay (2015) also reported that when CSR is integrated into the corporate reputation and becomes a public expectation, perceptions of irresponsibility can become a very important threat. Moreover, they added that when a crisis violates CSR expectations, the buffering value of CSR itself tends to be eliminated (Coombs \& Holladay, 2015). The two authors, however, did not provide any empirical verification of these effects and called for further empirical advancements in this direction. Finally, Vanhamme et al. (2015) argued that CSR could have buffering or aggravating effects depending on a contingency factor - the independence of the source in which the CSR communication appears. 
In summary, it seems that research on CSR crises has not reached a conclusion on whether a good CSR reputation can buffer or amplify the effects of CSR crises. We believe these mixed results might be due to the lack of joint consideration of the two concepts and their combined impacts on consumer reactions. We thus aim to contribute to this debate by better investigating the relationship between corporate reputation and CSR crises. In this regard, it is important to remark that we adopt a componential view of corporate reputation. According to this perspective (Fischer \& Reuber, 2007), reputation can be unbundled into different dimensions, and distinct companies might focus on specific dimensions to build their own reputations. For instance, when we think of a company that is well known for its CSR efforts, we know that CSR can address a variety of issues (e.g., diversity, education, economic development, environment, human rights) (Janssen et al., 2015). Among these different CSR dimensions, one specific component might play a primary role in the customers' perceptions of corporate reputation. For example, following the componential view described previously (Fischer \& Reuber, 2007), the company might be particularly reputed for its green politics or its good working environment.

Based on this assumption, we confront the case of CSR crises that imply a dimensional match (i.e., the crisis affects the same CSR dimension of prior good corporate reputation) with CSR crises that indicate a dimensional mismatch (i.e., the CSR crisis affects a different dimension with respect to prior good corporate reputation). We predict that, compared to a case of dimensional mismatch, in a case of dimensional match, consumers will perceive a higher level of incongruence, resulting in worse reactions toward the company itself. This argument is deeply explored in the following section. 


\section{Role of CPI in consumers' responses to crises}

When new information does not fit with previous expectations or beliefs held by the subject, a sensation of incongruence occurs (Maille \& Fleck, 2011). In the social cognitive literature, Heckler and Childers (1992) proposed that the perception of incongruence depends mainly on two dimensions: expectancy and relevancy of new information. Expectancy refers to the degree to which a piece of information falls into the predetermined structure of the theme evoked by the information. Relevancy refers to the information pertaining to the theme meaning, and it reflects how new information contributes to or detracts from clear identification of the theme. When new information is thus unexpected (i.e., it has a low probability of naturally appearing and does not fit with the expectations of the subject) and relevant (i.e., it significantly contributes to the theme definition), a sense of incongruence occurs (Lee \& Mason, 1999). In our case, we know from previous work that a crisis is, by definition, a relevant and unexpected event that threatens an organization (Coombs, 2007). A crisis is unexpected because, by its own nature, it suddenly erupts, breaking the general expectation that a company (above all, if reputable) will act properly. The relevancy of a crisis for the consumer arises from the crisis itself revealing some insight(s) concerning the company and its context. For instance, if the company is responsible for an environmental scandal, the crisis reveals a negative trait of the company, such as its limited attention to waste management or its lack of ecological awareness. Any crisis thus presents information for consumers that might induce the perception of incongruence. We add that when a crisis affects a company regarding an aspect for which the company has a good reputation (i.e., in case of dimensional match), consumers will consider the crisis more relevant and more unexpected; thus, they will experience a higher perception of incongruence compared to a crisis affecting other reputation dimensions (i.e., in case of dimensional mismatch). 
Cognitive dissonance theory (Cooper \& Fazio, 1984; Festinger, 1957; Hinojosa, Gardner, Walker, Cogliser, \& Gullifor, 2017) represents a theoretical perspective that supports this hypothesis. From previous work, we know that cognitive dissonance occurs when two relevant pieces of information are contradictory (Festinger, 1957; Hinojosa et al., 2017). Consequently, subjects feel the need to reconcile the incongruence. In this regard, we predict that if a crisis affects the same CSR dimension of a good company reputation (i.e., dimensional match), customers will experience the incongruence of a negative event that contradicts what the reputation upholds. Accordingly, the individuals will attempt to resolve their dissonance by applying dissonance-reduction strategies to either reinforce their perception of the corporate reputation (e.g., discarding the crisis as fake or irrelevant and confirming the good reputation of the company) or develop negative reactions toward the company. We might expect that customers would also give weight to a crisis due to its severity, and therefore the latter option would apply, with deterioration of the consumers' attitudes and behaviours toward the company. Indeed, negative information is often weighted more than positive information in shaping evaluations (Kahneman \& Tversky, 1979). In addition, individuals tend to consider negative information as more diagnostic than positive information: While "good" traits and behaviours are common and expected, "bad" traits and behaviours are more revealing (Fischer \& Reuber, 2007). In contrast, when a crisis affects a reputational dimension that does not characterize the company (i.e., dimensional mismatch), the crisis should be less diagnostic and thus have a lower impact in terms of consumer reactions.

Specifically, we focus on typical consumers' reactions to a CSR reputational crisis such as ATC, WOM, and PI. ${ }^{\mathrm{iii}}$ The preceding rationale leads to defining the following hypotheses. 
H1: In case of a dimensional match between corporate reputation and the crisis (high CPI), consumers react more negatively compared to a case of mismatch (low CPI), resulting in (a) less positive ATC, (b) less WOM, and (c) lower PI.

\section{Mediating role of discomfort}

Previous research has shown that cognitive dissonance generates first arousal and then a state of discomfort, which is a condition of psychological tension that troubles the individual (Elliot \& Devine, 1994). Festinger (1957), more specifically, alluded to dissonance as a bodily condition analogous to a state of tension or drive, akin to hunger. In his theory, this arousal triggers the individual to assess the situation (to understand the source of dissonance). Discomfort is, thus, the motivational driver of dissonance; in other words, it is responsible for stimulating individuals to apply dissonance-reduction strategies (soothing the discomfort). The relevance of discomfort in dissonance theory has been confirmed by the extant literature (Elliot \& Devine, 1994; Spangenberg, Sprott, Grohmann, \& Smith, 2003). In this regard, we believe that a high level of CPI (i.e., a case of dimensional match between corporate reputation and the crisis), compared to a low level (i.e., a case of dimensional mismatch), will generate a significantly higher state of discomfort, which is the motivational driver responsible for prompting the consumer to apply dissonance-reduction strategies. In other words, we predict that when consumers perceive a higher level of incongruence, compared to a lower level, they will worsen their evaluations of the company to eliminate the dissonance and resolve their state of discomfort. These dissonance-reduction strategies can include worsening ATC, lowering WOM, and reducing PI. Therefore, discomfort will mediate the impact of CPI on consumer reactions to crises, as formalized in the following hypotheses. 
H2: Discomfort mediates the negative impact that a high level of CPI (i.e., in cases of dimensional match), compared to a low level (i.e., in cases of dimensional mismatch), produces on consumer reactions in terms of (a) ATC, (b) WOM, and (c) PI.

\section{Situational Crisis Communication Theory and the Perception of Incongruence}

The situational crisis communication theory (Coombs, 2007) extends and applies the attribution theory (Weiner, 1985) and its assumptions about people's attributions of responsibility for events. It also provides a key framework for designing a crisis communication strategy by pairing the type of crisis with its most suitable post-crisis communication response. Specifically, it holds that the greater the stakeholders' attributions of organizational responsibility are for the crisis, the greater the threat is for the company. Accordingly, preventable types of crisis (e.g., company misdeeds), which are characterized by very strong attributions of responsibility on the part of the company, can be considered the most serious cases of crisis to address (Coombs, 2007; Coombs \& Holladay, 2012). In this regard, the situational crisis communication theory classifies post-crisis communication strategies into three groups: (a) the denial group (e.g., identifying a scapegoat, denying the crisis altogether); (b) the diminishing group (e.g., minimizing the company's responsibility or the perceived damage); and (c) the rebuilding group, which includes all post-crisis communication strategies that offer the victims material and/or symbolic forms of indemnification (including apology and compensation).

An apology is defined as an admission of blameworthiness and regret for an undesirable event (Coombs et al., 2010). This strategy, in fact, consists of conveying the message that the transgressor (e.g., the company) admits wrongdoing, feels remorse for it, and accepts responsibility for repairing the broken relationship (Barclay \& Skarlicki, 
2008). By doing so, an apology should restore the victim's dignity and affirm respect for the victim (Barclay \& Skarlicki, 2008). Moreover, an apology should signal that the transgressor will be trustworthy in the future, leading to the victim experiencing less fear and uncertainty about its intentions.

Compensation refers to an attempt to remedy the injustice by providing economic benefits to the victim (Coombs et al., 2010). This remedy could consist of directly paying an amount of money to the offended party or providing particular goods or services that have economic value. In this regard, previous research has provided some indications that financial compensation can be a useful way to repair commercial relationships (Desmet, de Cremer, \& van Dijk, 2010).

Notably, the situational crisis communication theory suggests that post-crisis communication strategies of rebuilding (apology and compensation) should be matched to preventable types of crises, such as the crises considered in our studies. However, experimental research on the efficacy of its guidelines has found mixed results (e.g., Claeys \& Cauberghe, 2014; Claeys, Cauberghe, \& Vyncke, 2010; Coombs \& Holladay, 1996). In general, Coombs et al. (2016) observed that previous studies too often drew "unfair" comparisons among post-crisis communication strategies by comparing apology with other strategies with different levels of accommodation. In this sense, apology and compensation are both accommodative (Bundy et al., 2016) and victimcentred strategies that attempt to transform an unjust situation into a just one (De Cremer, 2010); thus, they can be compared.

In particular, we predict that the strategy of apology will be more effective than that of compensation in reducing the state of discomfort induced by CPI. As emphasized by Newman and Kraynak (2013), in fact, an apology has both informative and emotional functions. That is, apology typically acknowledges guilt (Benoit \& Pang, 
2008), and by implementing this strategy, management accepts full responsibility for the crisis and asks stakeholders for forgiveness (Coombs, 2010; Tsarenko \& Tojib, 2015). We believe that this admission plays a key role in smoothing discomfort because it can better clarify the responsibility for the crisis and, in turn, can have positive effects on how individuals will attribute some dispositional traits to the company in cases of CPI.

Based on this rationale, we formulate the following hypotheses.

H3: Post-crisis communication strategies moderate the negative impact that discomfort produces on consumer reactions. In particular, an apology strategy outperforms a compensation strategy in reducing discomfort, in turn, affecting consumer reactions in terms of (a) higher ATC, (b) more intense WOM, and (c) higher PI.

\section{Methodology ${ }^{\mathrm{iv}}$ and results}

\section{Study 1}

The objective of this study was to empirically examine how consumers react in cases of dimensional matches between a good corporate CSR reputation and a crisis trigger event (i.e., high CPI) compared to a case of mismatch (i.e., low CPI).

\section{Pretest 1}

The purpose of this pretest was to (a) select the experimental scenarios to be used in Study 1 and (b) test the respondents' perceptions of incongruence. Through an online survey, 84 subjects were asked to rate the level of CPI between two stimuli concerning corporate reputation and a crisis scenario. We conducted a 2 (good corporate reputation based on green company vs. best place to work) $\times 2$ (crisis event: pollution vs. workers' exploitation) full-factorial analysis of variance (ANOVA) to assess the perception of 
incongruence on the part of respondents. In particular, we provided our informants with background information about a fictional industrial company, MSG, that manufactures smartphones. The company was presented as a firm particularly appreciated for its CSR initiatives. After the introductory description, each respondent received a stimulus in which the reason for the company's good reputation ("green company" or "best place to work") was manipulated ${ }^{\mathrm{v}}$. That is, the company was presented as one significantly concerned with environmental issues or, as an alternative, with its employees' work conditions. We then presented a crisis scenario in the form of a newspaper article. This article described a journalistic investigation showing that (a) the company was not as "green" as it seemed but rather used some illegal landfills to dispose of its most polluting production components or (b) the company was not the "best place to work" due to press charges of workers' exploitation. We finally asked our respondents to answer the following question measuring the level of CPI: "Based on what you have known about the company, please rate your perception of incongruence." We measured their responses with a 7 -point scale $(1=$ not at all incongruent, $7=$ very much incongruent), and as expected, we found that the interactive effect between our independent variables was significant $(F=697.08 ; p<0.001)$. Consequently, we concluded that our scenarios were perceived as having significant differences in terms of CPI. Importantly, when the crisis matched the same dimension of corporate reputation, the CPI was higher than in the case of mismatch $\left(\mathrm{M}_{\text {green }}\right.$ company_pollution $=5.80$ $>$ Mgreen company_workers' exploitation $=1.75 ; t=15.07, p<0.001 ;$ Mbest place to work_workers' exploitation $=6.33>$ Mbest place to work_pollution $=1.55 ; t=3.60, p<0.001)$. Based on this result, we used the same pattern of manipulation in Study 1. 


\section{Methods}

To test H1, we employed a 2 (good corporate reputation based on green company vs. best place to work) $\times 2$ (crisis event: pollution vs. workers' exploitation) betweensubjects full-factorial design. We again manipulated the CSR reputation of the company and the type of CSR crisis (whether affecting the CSR dimension for which the company was reputable or another dimension). As in Pretest 1, the participants were provided with background information about the fictional company MSG, which again was introduced as a firm manufacturing smartphones. To render the scenario even more realistic, MSG was described as a company that, in its home country (Indonesia ${ }^{\text {vi }}$ ), was appreciated for its good management approach, one that revolved around CSR initiatives. As in Pretest 1, the company's good reputation ("green company" or "best place to work") was then manipulated. After a distraction task, ${ }^{\mathrm{vii}}$ we asked about the personal relevance of the CSR dimension ("Personally, how important do you think it is for a company to have a good reputation for its environmental culture/attention to the working conditions of its employees?"; 1 = not at all important, 7 = very important) in building a company's reputation. Finally, a crisis scenario (“pollution” or "workers' exploitation") was presented exactly as in Pretest 1 . After reading the article, the subjects were asked to indicate their perceptions of the seriousness of the crisis ("Personally, how serious do you think it is for a company to be involved in an environmental/workers maltreatment crisis?"; 1 = not at all serious, $7=$ very serious) (Dawar \& Lei, 2009).

After reading the article, the subjects were asked to respond to various dependent variables $^{\text {viii }}$, which were measured as follows:

- ATC, using 9 items and a 9-point scale (semantic differential) drawn from Homer (1995) (Cronbach's $\alpha=0.96)$; 
- WOM, using 3 items and a 7-point scale $(1=$ totally disagree, $7=$ totally agree $)$ drawn from Arnett et al. (2003) (Cronbach's $\alpha=0.94)$;

- $\quad \mathrm{PI}$, using 3 items and a 7-point scale ( 1 = very unlikely, 7 = very likely) drawn from Burton et al. (1999) (Cronbach's $\alpha=0.92$ ).

We also measured the respondents' attitude toward the company's home country (Indonesia), using 3 items and a 7-point scale (unfavourable/favourable, bad/good, negative/positive) (Cronbach's $\alpha=0.82$ ), and some demographic data about the respondents, such as gender and age, to be used as covariates in the models. In the end, we administered manipulation checks regarding comprehension of the scenarios.

In total, 129 undergraduate students from a medium-size town in a Western European country participated in the experiment (average age 21 years; $45 \%$ male, $55 \%$ female) in return for extra credit. The sample was drawn from the student population at a medium-size communications college, so they had no specific background in management. The subjects were randomly assigned to one of the four experimental conditions and responded to the questionnaire in a classroom setting. For the product category, we chose smartphones because college students are familiar with and interested in them (Fredricksen, 2012). Importantly, students also tend to be concerned about CSR issues (Wagner, Lutz, \& Weitz, 2009).

\section{Results}

\section{Manipulation Check}

We ran four independent $t$ tests to determine whether respondents understood the experimental manipulation. The first set of tests aimed at checking the "good corporate reputation" manipulation. Specifically, the first test, in the first set, showed that the recognition of an "environmental culture" was significantly higher in the "green 


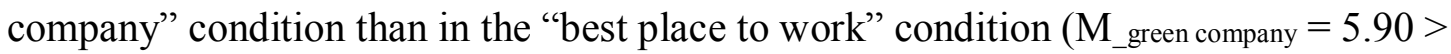
$\left.M_{\text {best place to work }}=1.32 ; t=20.59, p<0.001\right)$. The second test, in the first set, demonstrated that the recognition of a company that "pays particular attention to its employees" working conditions" was significantly higher in the "best place to work" condition than in the "green company" condition $\left(M_{-}\right.$green company $=1.67<\mathrm{M}_{-}$best place to work $=6.74 ; t=-25.41, p<0.001)$.

The second set of tests aimed to check the "crisis event" manipulation. Specifically, the first test, in the second set, showed that the manipulation of an “environmental crisis" was successful $\left(\mathrm{M} \_\right.$pollution $_{1}=6.23>\mathrm{M}_{-}$workers' exploitation $=1.36 ; t=$ 27.47, $p<0.001)$. The second test, in the second set, demonstrated that the manipulation of an “employees' crisis" was also successful $\left(M_{-}\right.$pollution $=1.90<\mathrm{M}_{-}$workers' exploitation $=$ $6.61 ; t=-17.62, p<0.001)$.

\section{Hypothesis Testing}

A $2 \times 2$ between-subjects analysis of covariance (ANCOVA) was then conducted to assess the impact of CPI (i.e., high vs. low) on our three dependent variables (i.e., ATC, WOM, and PI) after controlling for five covariates (Perdue \& Summers, 1986): gender $(1=$ male, 2 = female $)$; age; crisis seriousness; personal relevance of the CSR dimension; and attitude toward the company's home country. In particular, based on the results of our Pretest 1, we knew that the CPI is higher when the crisis matches the same dimension of CSR reputation and lower in cases of mismatch. In fact, our H1 implied an interactive effect between corporate reputation and crisis. We thus expected that, in cases of matches (i.e., high CPI), consumers would perform worse on the three dependent variables compared to cases of mismatches (i.e., low CPI). The predicted interaction effect was significant for all outcomes, as indicated in Table 1 (all $F>5.00$; all $p<0.05)$. Hence, simple main effects are inspected for each dependent variable. 
Table 1. Tests of Between-Subjects Effects (ANCOVA)

\begin{tabular}{|c|c|c|c|c|c|c|}
\hline Source & \multicolumn{2}{|c|}{ Dependent variable } & $\begin{array}{l}\text { Sum of } \\
\text { Squares }\end{array}$ & $d f$ & $\begin{array}{l}\text { Mean } \\
\text { Square }\end{array}$ & $\boldsymbol{F}$ \\
\hline \multirow[t]{3}{*}{ Crisis seriousness } & \multicolumn{2}{|c|}{ Attitude toward the corporation } & 34.94 & 1 & 34.94 & $14.77 * * *$ \\
\hline & \multicolumn{2}{|c|}{ Word of mouth } & 26.50 & 1 & 26.50 & $21.63 * * *$ \\
\hline & \multicolumn{2}{|c|}{ Purchase intention } & 5.42 & 1 & 5.42 & 3.07 \\
\hline Personal & \multicolumn{2}{|c|}{ Attitude toward the corporation } & 4.25 & 1 & 4.25 & 1.80 \\
\hline relevance of the & \multicolumn{2}{|c|}{ Word of mouth } & 11.97 & 1 & 11.97 & $9.76^{* *}$ \\
\hline CSR dimension & \multicolumn{2}{|c|}{ Purchase intention } & 0.99 & 1 & 0.99 & 0.56 \\
\hline \multirow[t]{3}{*}{ Gender } & \multicolumn{2}{|c|}{ Attitude toward the corporation } & 1.92 & 1 & 1.92 & 0.81 \\
\hline & \multicolumn{2}{|c|}{ Word of mouth } & 0.37 & 1 & 0.37 & 0.30 \\
\hline & \multicolumn{2}{|c|}{ Purchase intention } & 2.34 & 1 & 2.34 & 1.32 \\
\hline \multirow[t]{3}{*}{ Age } & \multicolumn{2}{|c|}{ Attitude toward the corporation } & 0.10 & 1 & 0.10 & 0.04 \\
\hline & \multicolumn{2}{|c|}{ Word of mouth } & 0.03 & 1 & 0.03 & 0.02 \\
\hline & \multicolumn{2}{|c|}{ Purchase intention } & 0.03 & 1 & 0.03 & 0.01 \\
\hline \multirow{3}{*}{$\begin{array}{l}\text { Attitude toward } \\
\text { the company's } \\
\text { home country }\end{array}$} & \multirow{2}{*}{\multicolumn{2}{|c|}{$\begin{array}{l}\text { Attitude toward the corporation } \\
\text { Word of mouth }\end{array}$}} & 0.05 & 1 & 0.05 & 0.01 \\
\hline & & & 1.95 & 1 & 1.95 & 1.59 \\
\hline & \multicolumn{2}{|c|}{ Purchase intention } & 0.19 & 1 & 0.19 & 0.11 \\
\hline \multirow{3}{*}{$\begin{array}{l}\text { Good corporate } \\
\text { reputation }\end{array}$} & & 0.42 & 1 & 0.42 & 0.18 \\
\hline & \multicolumn{2}{|c|}{ Word of mouth } & 0.26 & 1 & 0.26 & 0.21 \\
\hline & \multicolumn{2}{|c|}{ Purchase intention } & 3.55 & 1 & 3.55 & 2.01 \\
\hline \multirow[t]{3}{*}{ Crisis event } & \multicolumn{2}{|c|}{ Attitude toward the corporation } & 0.00 & 1 & 0.00 & 0.00 \\
\hline & \multicolumn{2}{|c|}{ Word of mouth } & 0.11 & 1 & 0.11 & 0.09 \\
\hline & \multicolumn{2}{|c|}{ Purchase intention } & 0.47 & 1 & 0.47 & 0.26 \\
\hline \multirow{3}{*}{$\begin{array}{l}\text { Good corporate } \\
\text { reputation } * \\
\text { crisis event }\end{array}$} & \multirow{2}{*}{\multicolumn{2}{|c|}{$\begin{array}{l}\text { Attitude toward the corporation } \\
\text { Word of mouth }\end{array}$}} & 18.58 & 1 & 18.58 & $7.85^{* *}$ \\
\hline & & & 13.88 & 1 & 13.87 & $11.32 * *$ \\
\hline & Purchase intentior & & 17.50 & 1 & 17.50 & $9.90 * *$ \\
\hline Mean Values and I & ifferences Between & roups & & & & \\
\hline & & Crisis & event & & & \\
\hline $\begin{array}{l}\text { Dependent } \\
\text { variable }\end{array}$ & $\begin{array}{l}\text { Good corporate } \\
\text { reputation }\end{array}$ & Pollution & $\begin{array}{l}\text { Workers' } \\
\text { exploitation }\end{array}$ & & $\begin{array}{l}\text { Niean } \\
\text { difference }\end{array}$ & $t$ \\
\hline $\begin{array}{l}\text { Attitude toward } \\
\text { the corporation }\end{array}$ & Green company & $3.26(0.29)$ & $4.16(0.31)$ & & -0.90 & $-2.06 *$ \\
\hline & $\begin{array}{l}\text { Best place to } \\
\text { work }\end{array}$ & $4.35(0.32)$ & $3.36(0.29)$ & & 0.99 & $2.29 *$ \\
\hline Word of mouth & Green company & $2.08(0.21)$ & $2.93(0.20)$ & & -0.86 & $-2.89 * *$ \\
\hline & $\begin{array}{l}\text { Best place to } \\
\text { work }\end{array}$ & $2.96(0.28)$ & $2.21(0.23)$ & & 0.74 & $2.03 *$ \\
\hline $\begin{array}{l}\text { Purchase } \\
\text { intention }\end{array}$ & Green company & $2.92(0.25)$ & $4.00(0.23)$ & & -1.08 & $-3.13^{* *}$ \\
\hline & $\begin{array}{l}\text { Best place to } \\
\text { work }\end{array}$ & $4.08(0.28)$ & $3.30(0.22)$ & & 0.77 & $2.12 *$ \\
\hline
\end{tabular}

Cases of dimensional match between good corporate reputation and crisis event are in bold.

$\mathrm{SD}$ in parentheses. 
$\mathrm{H} 1_{\mathrm{a}}$ is supported (see Fig. 1) because in cases of dimensional matches between CSR reputation and crisis (i.e., high CPI), ATC was lower than in cases of mismatches (i.e., low CPI) (Mgreen company_pollution $=3.26<\mathrm{M}_{\text {green company_workers' exploitation }}=4.16 ; t=-2.06, p<$ 0.05; Mbest place to work_workers' exploitation $=3.36<$ Mbest place to work_pollution $=4.35 ; t=-2.28, p<$ $0.05)$.

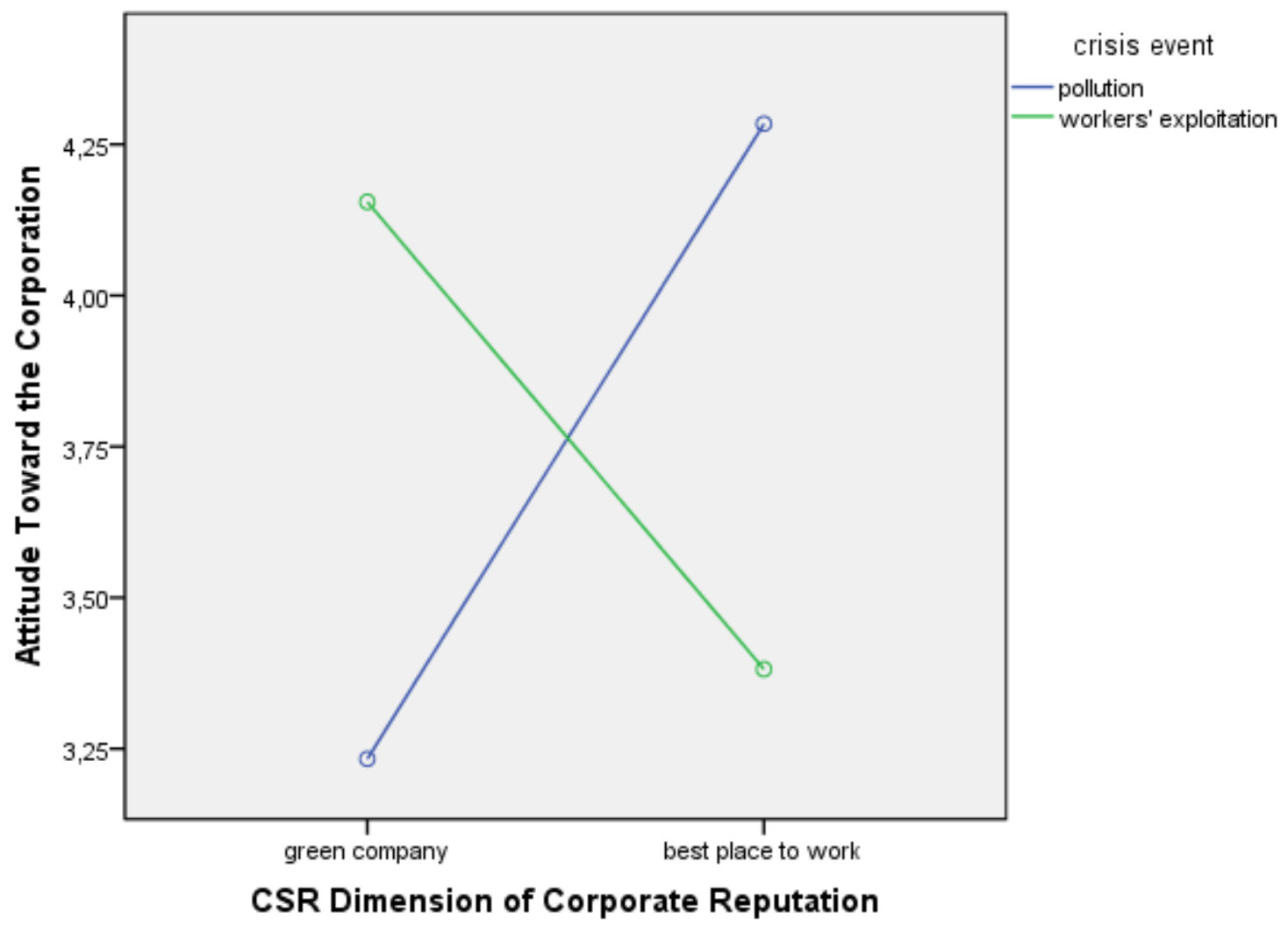


$\mathrm{H} 1_{\mathrm{b}}$ is supported (see Fig. 2) because in cases of dimensional matches between CSR reputation and crisis (i.e., high CPI), WOM was lower than in cases of mismatches (i.e., low CPI) (Mgreen company_pollution $=2.08<\mathrm{M}_{\text {green company_workers' exploitation }}=2.93 ; t=-2.89, p<$ 0.01 , and Mbest place to work_workers' exploitation $=2.21<$ Mbest place to work_pollution $=2.96 ; t=-2.33$, $p<0.05)$.

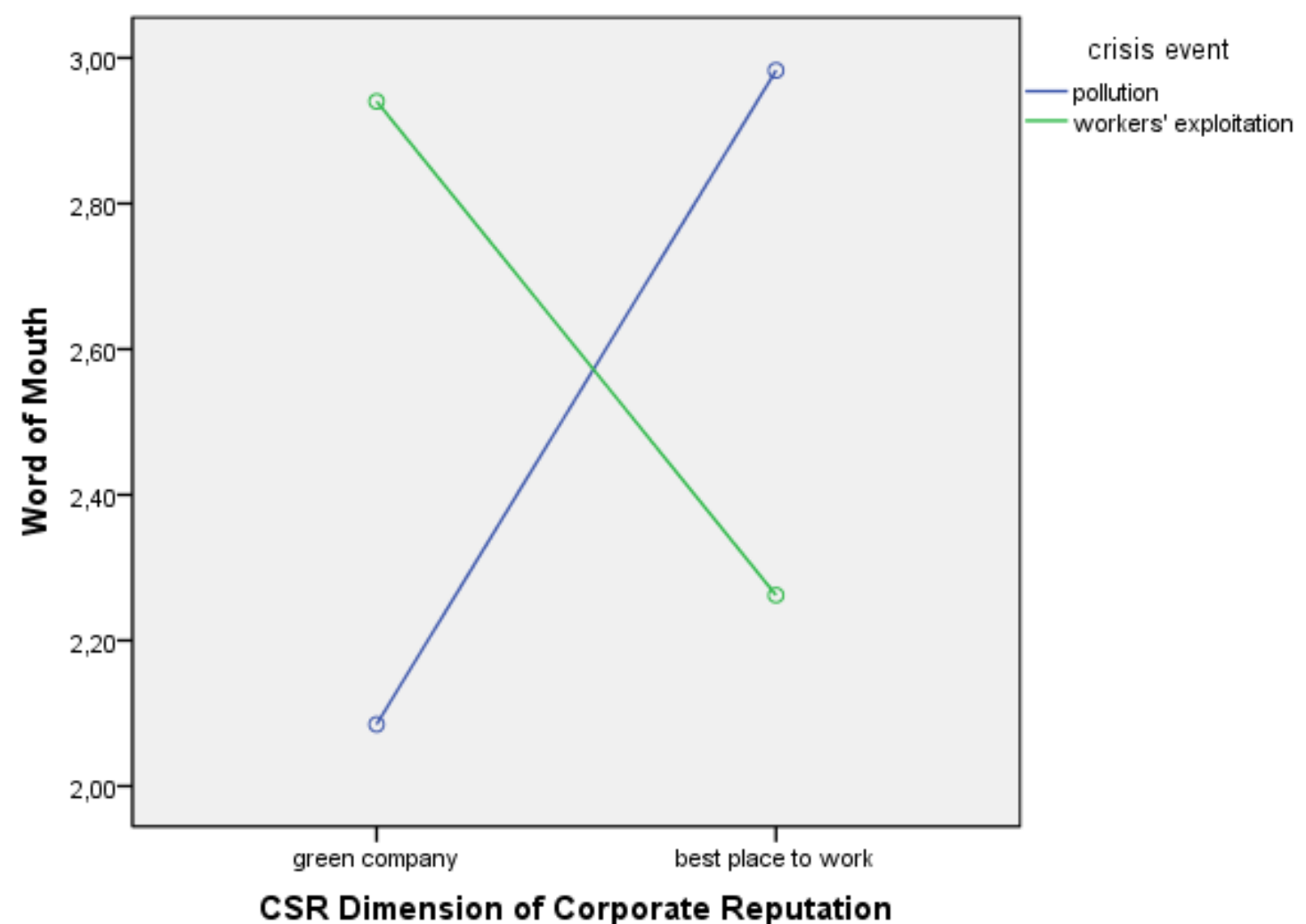


$\mathrm{H} 1_{\mathrm{c}}$ is supported (see Fig. 3) because in cases of dimensional matches between CSR reputation and crisis (i.e., high CPI), PI was lower than in cases of mismatches (i.e., low CPI $)\left(M_{\text {green company_pollution }}=2.92<\right.$ Mgreen company_workers' exploitation $=4 ; t=-3.13, p<0.01$, and Mbest place to work_workers' exploitation $=3.30<$ Mbest place to work_pollution $=4.08 ; t=-2.12, p<$ $0.05)$.

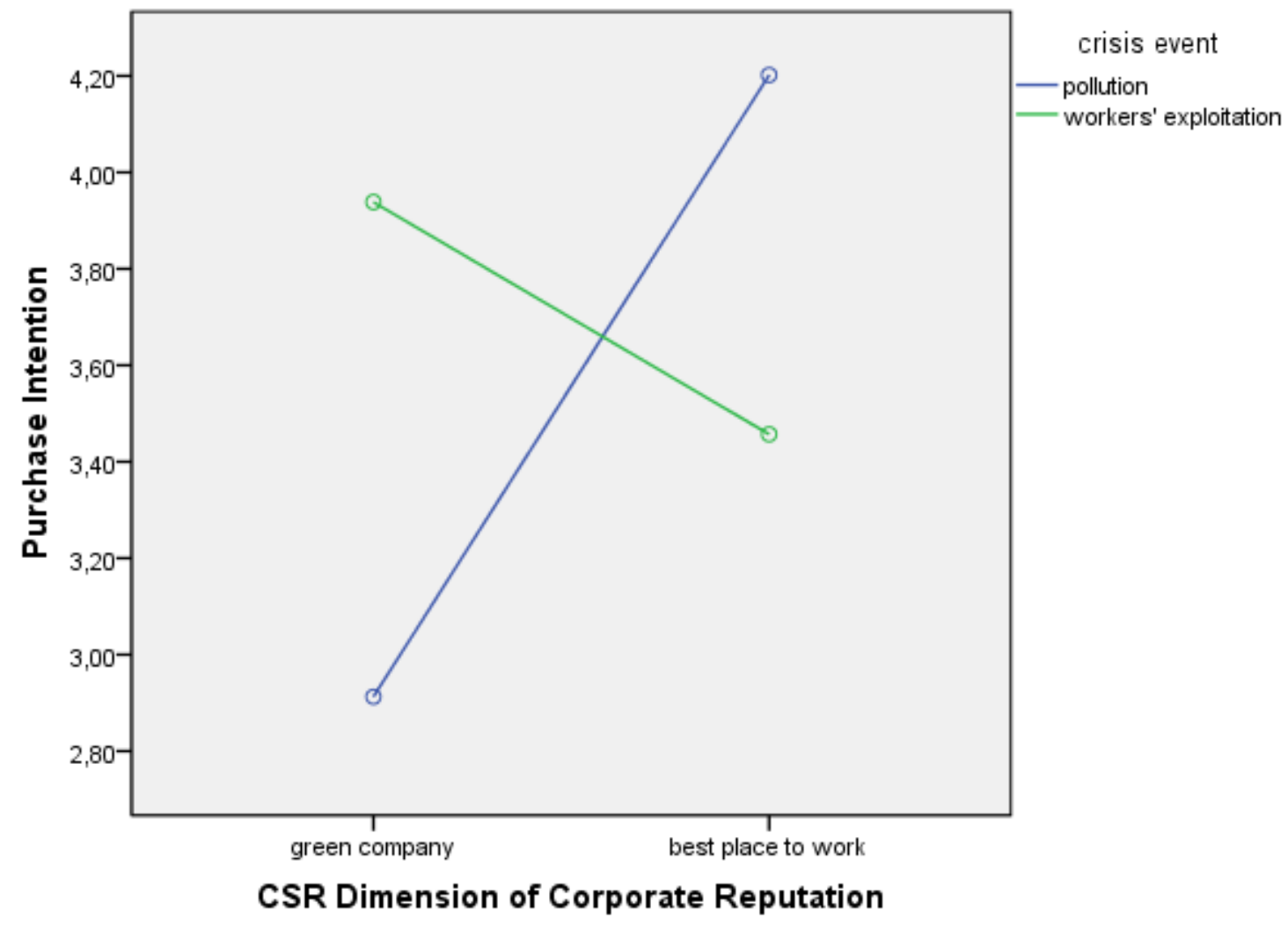




\section{Study 2}

The aims of Study 2 were to (a) replicate the results of Study 1 using a simpler design ${ }^{\text {ix }}$ and (b) test the role of discomfort as a mediating variable between CPI and consumer reactions to a crisis $(\mathrm{H} 2)$.

\section{Methods}

To test $\mathrm{H} 2$, we ran a 1 (good corporate reputation based on environmentalism) $\times 2$ (crisis event: pollution vs. workers' exploitation) between-subjects full-factorial design. The experimental procedure and stimuli were similar to those of Study 1 except that we manipulated only the dimension of the event that triggers the crisis. The company was always presented as a firm with a good reputation due to its environmental policy. The crisis scenario, instead, was based on pollution or, as an alternative, workers' exploitation. Based on the results of Study 1 (and Pretest 1), we knew that when the crisis involved the environmental dimension (i.e., pollution), it produced a higher CPI in our respondents because it contradicted the information that they had already been given (i.e., the company had a good reputation for its environmental policy).

Conversely, when the crisis regarded workers' exploitation, it did not directly contrast the previous information by causing lower CPI. As dependent variables, we measured the same variables as in Study 1: ATC (Cronbach's $\alpha=0.91)$, WOM (Cronbach's $\alpha=$ 0.94), and PI (Cronbach's $\alpha=0.96)$. We also measured discomfort as a psychological construct to function as a mediator with 3 items, using a 7 -point scale $(1=$ not at all, $7=$ very much) (Cronbach's $\alpha=0.75)$ (Elliot \& Devine, 1994). Finally, we performed a manipulation check and, as in Study 1, we measured the respondents' attitude toward the company's home country (Indonesia) (Cronbach's $\alpha=0.95$ ), personal relevance of the CSR dimension, crisis seriousness, gender, and age to be used as covariates in the models. 
In total, 120 undergraduate students from a medium-size town in a Western European country participated in the experiment (average age 21 years; 51\% male, $49 \%$ female) in exchange for extra credit. The sample was drawn from a student population at a large humanities college. The respondents did not have a background in management or business. The subjects were randomly assigned to one of the two experimental conditions, and they responded to the questionnaire in a classroom setting.

\section{Results}

\section{Manipulation Check}

We performed two $t$ tests to determine whether respondents understood the experimental manipulation. The first test showed that the recognition of an "environmental crisis" was significantly higher in the "pollution" condition than in the “workers' exploitation" condition $\left(\mathrm{M}_{\text {_pollution }}=6.16>\mathrm{M}_{\text {_workers' exploitation }}=1.73 ; t=\right.$ 13.00, $p<0.001)$. Analogously, the second test demonstrated that the scenario related to an "employees' crisis" was correctly identified by respondents who received the “workers' exploitation" information $\left(\mathrm{M} \_\right.$pollution $_{1}=1.24<\mathrm{M}_{-}$workers' exploitation $=5.73 ; t=$ $14.78, p<0.001)$.

\section{Hypothesis Testing}

Importantly, Study 2 confirmed the evidence that emerged in Study 1. Moreover, compared to the case of low CPI, subjects exposed to the case of high CPI also experienced significantly higher levels of discomfort, as shown in Table 2. 
Table 2. The F Tests of CPI Effects

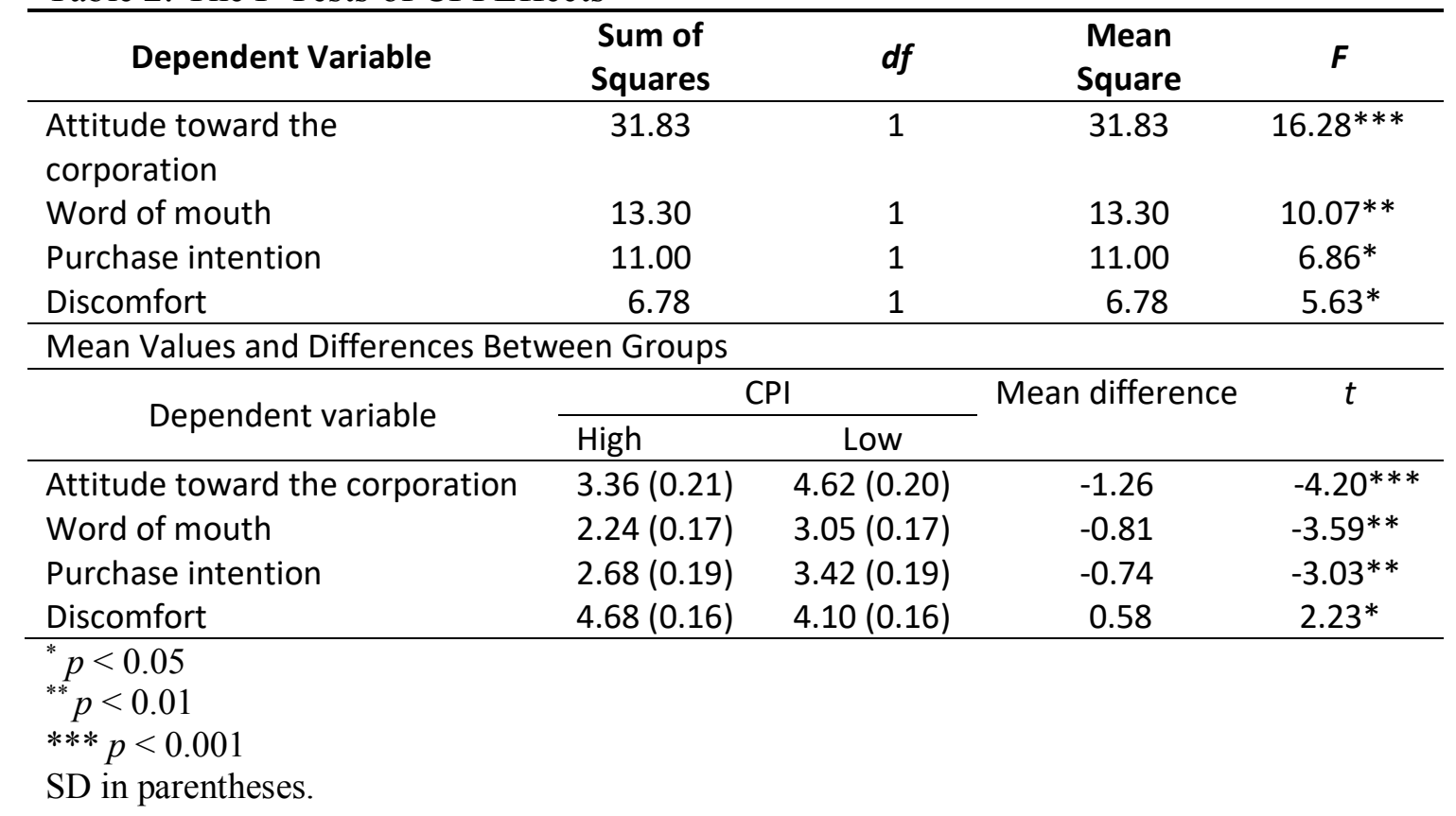


We thus used the macro PROCESS for SPSS developed by Hayes (2013) to test the mediation effect of discomfort between the perception of incongruence and the three dependent variables (i.e., H2). Specifically, we used Hayes' (2013) Model 4 with 5,000 bootstrapped samples (see also Zhao et al., 2010).

Table 3. Mediation Analyses

\begin{tabular}{|c|c|c|c|c|c|}
\hline & $b$ & $S E$ & $t$ & $\begin{array}{l}\text { BCa } 95 \% \\
\text { Cl lower }\end{array}$ & $\begin{array}{l}\text { BCa } 95 \% \\
\text { Cl upper }\end{array}$ \\
\hline \multicolumn{6}{|l|}{$\begin{array}{l}\text { Outcome variable attitude toward } \\
\text { the corporation (ATC) } \\
\text { Direct effects }\end{array}$} \\
\hline CPI on ATC (direct) (c) & -1.10 & 0.32 & $-3.44 * * *$ & & \\
\hline CPI on discomfort (a) & 0.66 & 0.24 & $2.73 * *$ & & \\
\hline Discomfort on ATC (b) & -0.27 & 0.13 & $-2.01 *$ & & \\
\hline \multicolumn{6}{|l|}{ Indirect effects } \\
\hline CPI on ATC via discomfort (c') & -0.18 & 0.12 & & -0.4958 & -0.0075 \\
\hline \multicolumn{6}{|c|}{$F(8 ; 89)=3.45 ; p<0.05 ; R$ Squared $=0.24$} \\
\hline \multicolumn{6}{|c|}{$\begin{array}{l}\text { Outcome variable word of mouth } \\
\text { (WOM) }\end{array}$} \\
\hline CPI on WOM (direct) (c) & -0.64 & 0.26 & $-2.44^{*}$ & & \\
\hline CPI on discomfort (a) & 0.63 & 0.24 & $2.60^{*}$ & & \\
\hline Discomfort on WOM (b) & -0.25 & 0.11 & $-2.24 *$ & & \\
\hline \multicolumn{6}{|l|}{ Indirect effects } \\
\hline CPI on WOM via discomfort ( $\left.c^{\prime}\right)$ & -0.15 & 0.10 & & -0.3962 & -0.0096 \\
\hline \multicolumn{6}{|c|}{$F(8 ; 87)=4.70 ; p<0.001 ; R$ Squared $=0.30$} \\
\hline \multicolumn{6}{|c|}{$\begin{array}{l}\text { Outcome variable purchase } \\
\text { intention (PI) }\end{array}$} \\
\hline CPI on PI (direct) (c) & -0.61 & 0.29 & $-2.09 *$ & & \\
\hline CPI on discomfort (a) & 0.63 & 0.24 & $2.60^{*}$ & & \\
\hline Discomfort on PI (b) & -0.26 & 0.12 & $-2.10^{*}$ & & \\
\hline \multicolumn{6}{|l|}{ Indirect effects } \\
\hline $\mathrm{CPI}$ on PI via discomfort $\left(\mathrm{c}^{\prime}\right)$ & -0.16 & 0.11 & & -0.4501 & -0.0141 \\
\hline \multicolumn{6}{|c|}{$F(8 ; 87)=2.74 ; p<0.01 ; R$ Squared $=0.20$} \\
\hline $\begin{array}{l}{ }^{*} p<0.05 \\
{ }^{* *} p<0.01 \\
* * * p<0.001\end{array}$ & & & & & \\
\hline
\end{tabular}

As shown in Table 3, compared to a case of low CPI, the perception of a high level of incongruence increased discomfort $(0.66 ; p<0.01)$, which, in turn, negatively affected ATC $(-0.27 ; p<0.05)$. The indirect effect of CPI on ATC through discomfort 
was negative and statistically significant (-0.18; CI -0.4958, -0.0075). A significant, negative direct effect of CPI remained on ATC $(-1.10 ; p<0.001)$, which led us to conclude that discomfort partially mediates the negative effect of CPI on ATC.

With regard to WOM and PI, we also found a significant mediating role of discomfort (see Table 3) and a significant direct effect of CPI, on WOM and PI respectively. Because the conditions for mediation were met (Zhao et al., 2010), but a direct effect of CPI on consumer attitudes and behaviours still remains, we can thus only partially confirm $\mathrm{H} 2$. That is, although the mediation effect of discomfort was found to be only partial, we can still conclude that this variable plays a statistically significant role in mediating the aggravating effects of CPI on consumer reactions after a crisis. This result opens the door to future studies because even if the mediator identified is consistent with the hypothesized theoretical framework, we have to consider the likelihood of one or more "omitted" mediators in the direct path.

\section{Study 3}

Studies 1 and 2 showed how CPI aggravates post-crisis consumer reactions due to an increased state of discomfort. Study 3, referring to the situational crisis communication theory (Coombs, 2007), aimed to assess how alternative corporate post-crisis communication strategies work differently in attenuating discomfort.

\section{Pretest 2}

The purpose of this second pretest was to (a) select and verify the credibility of the experimental scenarios and (b) test the respondents' perceptions of fairness between the two post-crisis communication strategies. In this regard, the literature has emphasized that there may be various types of apologies (full vs. partial; Newman \& Kraynak, 2013; Roschk \& Kaiser, 2013) and various type of compensation (goods vs. money, 
with different amounts: undercompensation, compensation, overcompensation; Haesevoets et al., 2013). To be compared, corporate post-crisis response strategies should thus be perceived equally fair in restoring the victim's sense of justice.

For this purpose, we created two comparable scenarios: a full apology scenario and a monetary compensation scenario. Both scenarios were based on their essential definitions.

Through an online survey, 58 subjects (average age 22 years; $52 \%$ male, $48 \%$ female) were exposed to a crisis scenario similar to "the pollution" scenario used in Study 2, randomly assigned to one of the two response strategies conditions (apology vs. compensation), and asked to rate the fairness of the response strategy. The results showed that there was no significant difference in terms of perceived fairness between the two response strategies $\left(\mathrm{M}_{-}\right.$apology $=3.89$ vs. $\mathrm{M} \_$compensation $\left._{1}=3.65 ; t=0.61, p>0.05\right)$; hence, we concluded that the two scenarios of apology and compensation could be considered comparable and could be used in our Study 3.

We also included two manipulation check items pertaining to understanding of the crisis response strategies used by the company: "the company accepted responsibility for the incident and asked for forgiveness" $(1=$ strongly disagree, $7=$ strongly agree $)\left(\mathrm{M}_{-}\right.$apology $\left.=6.57>\mathrm{M}_{\text {compensation }}=1.39 ; t=23.28, p<0.001\right)$ and "the company gave money as a one-off contribution" $(1=$ strongly disagree, $7=$ strongly agree $)\left(\mathrm{M}_{-}\right.$apology $\left.=1.40<\mathrm{M}_{\text {compensation }}=6.43 ; t=-26.12, p<0.001\right)$. In summary, the manipulations were successful because both strategies were perceived as intended (Perdue \& Summers, 1986).

Finally, credibility was assessed on a 7-point semantic differential item scale asking respondents to indicate whether the depicted situation was unrealistic $(=1)$ or realistic $(=7)$. Mean scores of 5.47 for apology and 5.54 for compensation suggest that 
the respondents perceived the situation as credible and believable (Liao, 2007) and that there were no differences between the two scenarios $(t=-2.22, p>0.05)$.

\section{Methods}

To test $\mathrm{H} 3$, we ran a 1 (good corporate reputation based on environmentalism) $\times 2$ (crisis event: pollution vs. workers' exploitation) $\times 2$ (crisis response strategy: apology vs. compensation) between-subjects full-factorial design. The experimental procedure was similar to that used in Study 2. That is, the company was first described as a firm with a strong reputation in terms of environmental policy. Then, a critical event was introduced that could focus on pollution or, as an alternative, workers' exploitation. Based on our previous studies, we considered the crisis related to pollution to be perceived as highly incongruent (due to the presentation of the firm as one that pays special attention to environmental issues). After the crisis scenario, the participants were exposed to a corporate response strategy stimulus ("apology" or "compensation") in the form of a press release. The response strategy was manipulated by including a quote from the company's CEO: In the case of "apology," the CEO accepted responsibility and asked for forgiveness, and in the case of "compensation," the CEO proposed a onetime economic contribution for families living near the polluting factory.

As dependent variables, we measured the same variables as in the previous studies: ATC (Cronbach's $\alpha=0.87$ ), WOM (Cronbach's $\alpha=0.87$ ), and PI (Cronbach's $\alpha=0.94$ ). We also measured discomfort (Cronbach's $\alpha=0.80$ ) as a psychological construct to function as a mediator and the respondents' attitude toward the company's home country (Indonesia) (Cronbach's $\alpha=0.92$ ), personal relevance of the CSR dimension, crisis seriousness, gender, and age to be used as covariates in the models. Further, we ran two manipulation checks to verify the correct comprehension of the crisis events and corporate response strategies. 
In total, 128 undergraduate students from a medium-size town in a Western European country participated in the study (average age 21 years; 51\% male, 49\% female) in exchange for extra credit. The sample was drawn from a student population at a medium-size communications college, so they did not have a specific background in management or business studies. The subjects were randomly assigned to one of the four experimental conditions and responded to the questionnaire in a classroom setting.

\section{Results}

\section{Manipulation Checks}

We performed two $t$ tests to determine whether respondents understood the experimental manipulations. The first showed that the scenario related to an "environmental crisis" was well understood by our respondents who received the "pollution" condition $\left(\mathrm{M}_{\_}\right.$pollution $=6.29>\mathrm{M}_{-}$workers' exploitation $\left.=1.94 ; t=19.91, p<0.001\right)$. The second demonstrated that the scenario related to an "organizational employees' crisis" was also well understood by the respondents in the "workers" exploitation" condition $\left(\mathrm{M} \_\right.$pollution $_{1}=1.44<\mathrm{M}_{-}$workers' exploitation $\left.=6.49 ; t=-27.36, p<0.001\right)$. Similarly, to check the variable "crisis response strategy," we performed two further $t$ tests. In the first, we checked the "apology scenario," the manipulation of which was successful $\left(\mathrm{M}_{\text {apology }}=6.39>\mathrm{M}_{-}\right.$compensation $\left.=1.66 ; t=21.30, p<0.001\right)$. In the second, we checked the "compensation scenario," the manipulation of which was also successfully established $\left(\mathrm{M} \_\right.$apology $_{1}=1.86<\mathrm{M}_{-}$compensation $\left.=6.32 ; t=-17.30, p<0.001\right)$.

\section{Hypothesis Testing}

Study 3 confirmed the main findings of Studies 1 and 2. Moreover, Study 3 addressed the specific predictions of $\mathrm{H} 3$, which suggests that post-crisis communication strategies moderate the negative impact that discomfort produces on consumer reactions in terms 
of ATC, WOM, and PI. To test the moderated mediation models hypothesized in H3, we used the macro PROCESS for SPSS (Hayes, 2013). In particular, we used Hayes' (2013) Model 14 with 5,000 bootstrapped samples (see also Zhao et al., 2010).

Table 4. Moderated Mediation Analyses (Attitude Toward the Corporation)

\begin{tabular}{|c|c|c|c|c|}
\hline & \multicolumn{2}{|c|}{$\begin{array}{l}\text { Mediator variable } \\
\text { model: Discomfort }\end{array}$} & \multicolumn{2}{|c|}{$\begin{array}{l}\text { Outcome variable model: } \\
\text { Attitude toward the } \\
\text { corporation }\end{array}$} \\
\hline & $B$ & $t$ & $b$ & $t$ \\
\hline Constant & -3.93 & $-3.06 * * *$ & 4.57 & $4.05^{* * *}$ \\
\hline $\mathrm{X}: \mathrm{CPI}$ & 1.13 & $4.21 * * *$ & -0.56 & $-2.32 * *$ \\
\hline $\begin{array}{l}\text { Personal relevance of the CSR } \\
\text { dimension }\end{array}$ & 0.50 & $3.70 * * *$ & -0.07 & -0.54 \\
\hline Crisis seriousness & -0.14 & -1.22 & 0.02 & 0.15 \\
\hline $\begin{array}{l}\text { Attitude toward the company's home } \\
\text { country (Indonesia) }\end{array}$ & -0.05 & -0.54 & 0.09 & 1.00 \\
\hline Age & 0.02 & 0.49 & 0.02 & 0.62 \\
\hline Gender & -0.13 & -0.50 & 0.26 & 1.26 \\
\hline M: Discomfort & & & -0.14 & $-1.82 * *$ \\
\hline V: Response strategy & & & -0.77 & $-3.53 * * *$ \\
\hline $\mathrm{X} * \mathrm{~V}$ & & & -0.29 & $-2.02 * *$ \\
\hline \multicolumn{5}{|c|}{$\begin{array}{l}\text { Bootstrap 95\% Confidence Intervals for Conditional Indirect Effect - Bias Corrected and } \\
\text { Accelerated (BCa) }\end{array}$} \\
\hline \multirow{3}{*}{ M: Discomfort } & $\begin{array}{c}\text { Response } \\
\text { strategy }\end{array}$ & Effect & Lower & Upper \\
\hline & Apology & -0.00 & -0.2649 & 0.2286 \\
\hline & Compensation & -0.33 & -0.7290 & -0.0658 \\
\hline \multicolumn{5}{|c|}{$R$ Squared $=0.25 ;$ Index of moderated mediation: $-0.33(\mathrm{Cl}-0.76,-0.01)$} \\
\hline $\begin{array}{l}{ }^{*} p<0.05 \\
{ }^{* *} p<0.01 \\
*_{* * *} p<0.001 \\
\quad \text { Under the mediator variable }\end{array}$ & nodel, we found & that CPI $h$ & a statistic & \\
\hline \multicolumn{5}{|c|}{ significant effect on the level of discomfort felt by consumers $(1.13, t=4.21, p<$} \\
\hline \multicolumn{5}{|c|}{ 0.001). This effect remained statistically significant after controlling for several } \\
\hline \multicolumn{5}{|c|}{ covariates. Under the outcome variable models, we found that discomfort significantly } \\
\hline \multicolumn{5}{|c|}{ influenced the three dependent variables: ATC $(-0.14, t=-1.82, p<0.01)$, WOM $(-0.13$, } \\
\hline \multicolumn{5}{|c|}{$t=-1.87, p<0.01)$, and PI $(-0.19, t=-1.94, p<0.01)$. We also found that CPI had a } \\
\hline significant direct & ende & & $0, l=$ & \\
\hline
\end{tabular}


0.01), WOM (-0.46, $t=-2.09, p<0.01)$, and PI $(-0.56, t=-1.86, p<0.01)$. These

results confirmed what we demonstrated in Study 2.

Table 5. Moderated Mediation Analyses (Word of Mouth)

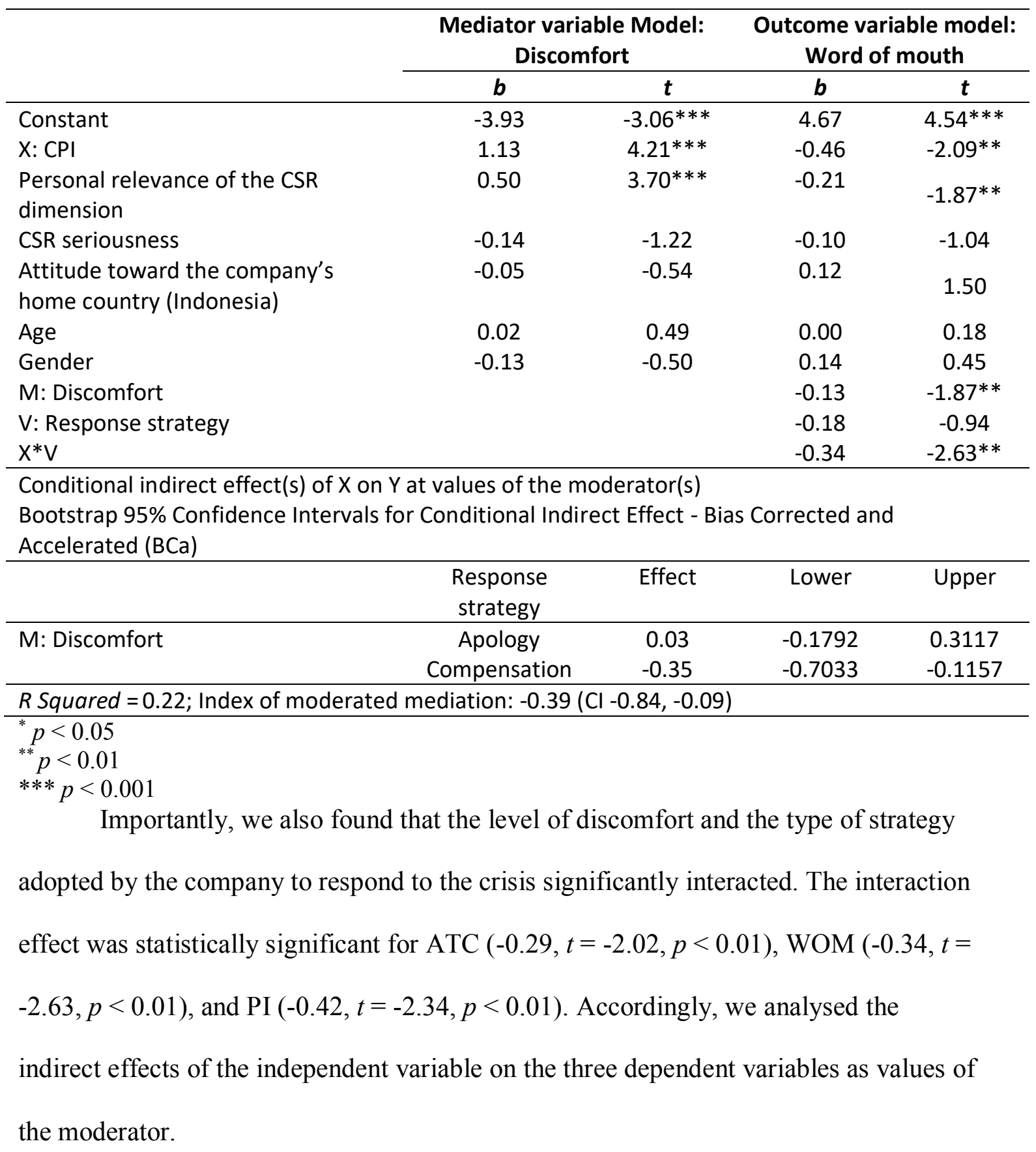


Table 6. Moderated Mediation Analyses (Purchase intention)

\begin{tabular}{lcccc}
\hline & \multicolumn{2}{c}{$\begin{array}{c}\text { Mediator variable Model: } \\
\text { Discomfort }\end{array}$} & \multicolumn{2}{c}{$\begin{array}{c}\text { Outcome variable model: } \\
\text { Purchase intention }\end{array}$} \\
\cline { 2 - 5 } & $\boldsymbol{b}$ & $\boldsymbol{T}$ & $\boldsymbol{b}$ & $\boldsymbol{t}$ \\
\hline Constant & -3.93 & $-3.06^{* * *}$ & 3.15 & $2.25^{* *}$ \\
X: CPI & 1.13 & $4.21^{* * *}$ & -0.56 & $-1.86^{* *}$ \\
Personal relevance of the CSR & 0.50 & $3.70^{* * *}$ & -0.02 & -0.10 \\
dimension & & & & 0.34 \\
Crisis seriousness & -0.14 & -1.22 & 0.04 & 0.34 \\
Attitude toward the company's home & -0.05 & -0.54 & 0.19 & $1.79^{* *}$ \\
country (Indonesia) & & & & 0.69 \\
Age & 0.02 & 0.49 & 0.03 & 0.57 \\
Gender & -0.13 & -0.50 & 0.15 & $-1.94^{* *}$ \\
M: Discomfort & & & -0.19 & -1.43 \\
V: Response strategy & & & -0.39 & $-2.34^{* *}$ \\
X*V & & & -0.42 & \\
\hline
\end{tabular}

Conditional indirect effect(s) of $\mathrm{X}$ on $\mathrm{Y}$ at values of the moderator(s)

Bootstrap 95\% Confidence Intervals for Conditional Indirect Effect - Bias Corrected and Accelerated (BCa)

\begin{tabular}{|c|c|c|c|c|}
\hline & $\begin{array}{l}\text { Response } \\
\text { strategy }\end{array}$ & Effect & Lower & Upper \\
\hline \multirow{2}{*}{ M: Discomfort } & Apology & 0.01 & -0.2766 & 0.3941 \\
\hline & Compensation & -0.46 & -0.9240 & -0.1450 \\
\hline
\end{tabular}

$R$ Squared $=0.18 ;$ Index of moderated mediation: $-0.47(\mathrm{Cl}-1.09,-0.07)$

${ }^{*} p<0.05$

${ }^{* *} p<0.01$

$* * * p<0.001$

At the bottom of the Table 4, we can see how the indirect effect of CPI on ATC, mediated by the level of discomfort, was not significantly different from zero in the case of an apology $(-0.00 ;$ CI $-0.2649,0.2286)$. In fact, the bootstrap interval included zero.

Conversely, in the case of compensation, the effect was significantly negative because the bootstrap interval did not include zero (-0.33; CI -0.7290, -0.0658) (Zhao et al., 2010). The same result was found for the other two dependent variables (see Tables 5 and 6).

These results confirm that, for all three dependent variables that we analysed, the indirect effect of CPI via discomfort was statistically significant and negative only if the company decided to respond to the crisis using the strategy of compensation.

Conversely, if the company chose to employ the strategy of apology, the negative effect of CPI on the three dependent variables, mediated by the level of discomfort, was no 
longer significant. Because consumer responses can be considered less negative in cases of apology, these findings lead us to confirm H3.

\section{General discussion}

The current literature highlights the importance of CSR in building a strong, positive reputation among a company’s stakeholders (Kang, Germann, \& Grewal, 2016). However, it also shows that building a reputation on CSR can paradoxically be risky because crises often affect CSR dimensions such as environmentalism, social issues, and human rights (Coombs \& Holladay, 2015). In other words, when stakeholders perceive that a corporation with a reputation based on CSR is actually acting irresponsibly, the resulting crisis may be particularly difficult to manage (Coombs \& Holladay, 2015; Tsarenko \& Tojib, 2015; Wagner et al., 2009). In this regard, our Study 1 introduces the concept of CPI to the crisis management literature. In particular, we demonstrated that in case of a dimensional match between the CSR dimension that is central to a corporation's reputation (e.g., environmentalism) and the CSR dimension that is affected by a crisis (e.g., a crisis damaging the environmental record of a company known for its environmentalism), consumers perceive a higher level of incongruence compared to a case of mismatch. The higher that CPI is, the worse that consumer reactions to the crisis are, in terms of ATC, WOM, and PI. ${ }^{\mathrm{x}}$ These empirical evidences seems to be coherent with the expectancy violation theory (Burgoon, 1993), which posits that higher expectancies may lead to more severe punishment. In fact, in case of high CPI, the organization will be punished even more harshly for its violation of stakeholders' high-level expectancies compared to a lower level of CPI.

In Study 2, we then identify one psychological mechanism (discomfort) that contributes to the explanation of why crises that match the CSR dimension for which the corporate is reputable have a worse impact on consumer reactions. In particular, we 
found that a state of discomfort on the part of consumers partially mediates the negative effects of CPI on consumer reactions. This mediating effect of discomfort, even if only partial, suggests that the negative impact might be due to a sense of cognitive dissonance (Elliot \& Devine, 1994; Hinojosa et al., 2017), which is particularly experienced by consumers exposed to crises creating high CPI. Our findings thus extend the spectrum of consumer-based variables involved in a crisis and, at the same time, leave the door open to future studies because a direct effect of CPI on consumer reactions still remains to be explained by other mediators. Although the extant literature includes a variety of effects on consumers (e.g., emotional states, ethical considerations), cognitive dissonance is a further inner state to consider. In addition, cognitive dissonance has a double nature in terms of the cognitive assessment of a situation and the emotional state (i.e., discomfort); therefore, it describes well the complex circumstances experienced by a consumer in a crisis.

In Study 3, we further illustrate how alternative corporate crisis communication strategies (apology or compensation) can differently modulate the negative effect of CPI on consumer reactions. By building on situational crisis communication theory (Coombs, 2007), we demonstrate that the type of response strategy used by a company in a crisis can moderate the negative effect of CPI via discomfort on consumers' reactions to crises. More specifically, we argue that the rebuilding strategies (i.e., apology and compensation) proposed by situational crisis communication theory in cases of preventable crises have different impacts on consumers when CPI occurs. Although the strategies tend to be interchangeable in cases of crises that generate low CPI, in cases of high CPI, apology seems to have a better effect on consumer responses compared to compensation. 


\section{Theoretical implications}

Our three studies contribute to the extant literature on crisis management in three main ways. First, we introduce a new boundary and situational condition to the literature, namely the match/mismatch between the crisis and CSR reputation and the related CPI (Studies 1 and 2). The introduction of CPI contributes to the clarification of the debate about whether reputation acts as a buffer or a burden in cases of crises. In fact, research about the effects of an organization's general reputation following a negative event remains equivocal (Zavyalova et al., 2016). To this end, we argue that CPI is a condition contingent on the type of crisis (matching or not the CSR reputation of the company), which can be considered to verify whether CSR reputation is a buffer or a burden. The introduction of the concept of CPI might therefore help us better understand why the extant literature has found that the buffering effect works on some occasions and not others. In fact, we can consider CPI to be a key variable in understanding the boundary conditions of the buffering effect. The higher the expectancy in which the target firm was held by stakeholders (i.e., high CPI), the greater the deterioration in their attitudes and behaviours toward the firm, resulting in backfiring, or what Sohn and Lariscy (2015) call the "boomerang effect" of reputation.

Study 3 also provides suggestions on how to address a CSR crisis depending on the factor of match/mismatch and related CPI. Notably, the contributions of our three studies are in agreement with the current call in the literature on CSR crisis for a renewed effort in studying situational conditions (Coombs, 2016) for crisis response strategies: CSR-based crisis response messages must be analysed in terms of other situational variables present in a crisis (Janssen et al., 2015). In other words, CSR-based crisis response messages should be carefully crafted based on situational factors particular to a given crisis situation (Ham \& Kim, 2017). 
Second, the introduction of the concept of CPI contributes to the emerging trend in the literature on crisis management, which focuses on the inner states of individuals facing a CSR crisis (Grappi \& Romani, 2015). Traditional crisis management emphasizes how the response strategy should raise rise from the type of crisis (ranging from accidental to preventable), without focusing on the individuals' inner states that determine their reactions. Our work, conversely, adds to the new approach: Studies 1 and 2 introduce the notion of CPI and investigate the state of discomfort following a CSR crisis. In this regard, we also introduce some additional knowledge compared to the study by Wagner et al. (2009). These authors, in particular, investigated consumers' perceptions of hypocrisy of a company when a CSR crisis occurs. Their work focused more on the attribution of hypocritical trait of the company by consumers and less on the inner state of the consumers facing a CSR crisis. Consequently, they did not explore the inner state experienced by individuals when a perception of incongruence occurs after a crisis. Instead, consistently with current streams of research on CSR and crises, which focus more significantly on the emotions and inner states of individuals facing a company crisis [e.g., anger and sympathy (Gistri, Corciolani, \& Pace, 2018; Grappi \& Romani, 2015); anger, regret, and guilt (Joireman, Smith, Liu, \& Arthurs, 2015); forgiveness (Tsarenko \& Tojib, 2015)], we believe that it is fundamental to also study the inner states of consumers, such as the state of discomfort that we explored in Study 2.

Third, we contribute to the crisis communication literature by showing that when CPI is considered, the two rebuild strategies of apology and compensation work differently in attenuating negative consumer reactions.

Studies on situational crisis communication theory have established the main effects and consolidated the key tenets of crisis communication. Current advancements 
have moved toward research on boundary conditions and the moderating effects of this theory (Coombs, 2016). Our findings help improve this literature by emphasizing that apology and compensation, which most scholars have proposed as substitutable strategies for preventable crises (Coombs, 2007), are instead different when CPI is considered. In particular, in the case of high CPI, it seems that an apology strategy may be more effective than compensation in reducing discomfort and lessening the consumers' negative reactions toward the company. This is coherent with the recent literature, which notes that consumers actively interpret the situation and, in turn, cope with a corporation's crisis response strategy (Ham \& Kim, 2017).

\section{Managerial implications}

Conceptually, a company with a favourable reputation is argued to be able to attract support from stakeholders (Grund \& Fombrun, 1996). Specifically, support in various forms from customers (e.g., positive references, willingness to pay premium prices) is of particular interest because it represents social endorsement from virtually the most important stakeholder of any company (Srivoravilai, Melewar, Liu, \& Yannopoulou, 2011). Moreover, with social media, reputation management requires businesses to work in partnership with diverse stakeholder groups, such as consumers, who are constantly playing the role of citizen journalists (Jones, Temperley, \& Lima, 2009). In other words, corporate reputation is not solely in the hands of management teams. Rather, the process of managing corporate reputation is increasingly shared, which inevitably brings additional risk factors (Rokka, Karlsson, \& Tienari, 2014). This is more true if we consider the social expectations linked to a strong CSR reputation (Sohn \& Lariscy, 2015). In this scenario, positive and negative news about a company spreads quickly, especially when negative events such as crises occur. To have more control over and to mitigate the negative outcomes for the company, it is fundamental for 
managers to implement a culture of prevention based on the identification and control of reputational risks. To this aim, the current research suggests to managers the importance of considering CPI. Results of Studies 1 and 2 showed that when CPI is high, outcomes will be more negative compared to when it is low. Accordingly, it becomes important to analyse, as soon as possible, whether a crisis is matching the same CSR dimension of corporate reputation. In this case, in fact, it could produce a high level of CPI, which will require the company to implement the most appropriate strategy to contain the damage. This is especially relevant if we consider that consumers are not necessarily rational, well informed, or inclined to seek complete information before making causal inferences regarding who should be responsible in a crisis scenario (Gao, Knight, Zhang, Mather, \& Tan, 2012). In addition, as Yannopoulou, Koronis, and Elliott (2011) noted, media amplify consumers' negative reactions to brand crises. Hence, keeping control over the salient dimension of corporate reputation may be strategically key to prompting the company to answer correctly in the case of a crisis. Effective brand crisis management should adjust to the media and public concerns.

In particular, although the strategy of apology has been shown to be more expensive than compensation (Coombs \& Holladay, 2008), in cases of high CPI, this strategy has a significantly better efficacy than compensation. A public apology is necessary as part of organizational efforts to argue that errors will be corrected and things should go back to normal; it is the projected return to normalcy that reinforces trust and ensures the survival and continuity of a brand's life (Yannopoulou et al., 2011). In cases of low CPI, in contrast, the managerial indication drawn from our Study 3 is that a compensation strategy should be implemented rather than an apology strategy because the two alternatives seem to be equally effective in these cases. Therefore, although in the latter case, compensation is as efficient as apology in attenuating 
consumer negative reactions toward the company, it should be preferred because it tends to be more sustainable in terms of cost reduction.

\section{Limitations and future research}

We conclude by acknowledging that our studies are not without limitations and by offering some insights for future research. For instance, in Studies 2 and 3, we found three mediating effects that were partial, but not complete. We maintained the state of discomfort as our main mediating variable because we believed it was important to introduce the idea of cognitive dissonance to the crisis management literature. However, due to the results of partial mediation, we are aware that other constructs might also mediate the relationship between CPI and consumer responses. Anger, honesty, trustworthiness, and forgiveness, which previous literature investigated in different crises contexts, are certainly good candidates for further studies designed to investigate the relationship between CPI and consumer reactions.

Moreover, all our scenarios address the context of CSR. Although we are confident that this context is important to analyse, we believe CPI could have a broader importance for the management of crises. In our view, other types of crises (e.g., corporate ability crises such as product flaws) can also be influenced by CPI. However, because we did not focus on these specific cases in the present article, we leave this view for future development. Because, in our experiments, we used a fictional company, future research could also replicate our study in a real-life situation to increase the external validity of our findings.

Finally, in our Study 3, we considered only one type of apology and only one type of compensation (i.e., their prototypical forms). Future research could instead compare some of the variants of these strategies and other strategies with different features. Moreover, the crisis management literature has usually considered the 
rebuilding strategies of apology and compensation separately, without assessing their potential combinations. Future studies might thus investigate the combined effect of the two strategies (Haesevoets et al., 2013), particularly in cases of crises characterized by a high level of CPI. 


\section{Appendix A. Scales and items}

Attitude toward the company's home country

Unfavorable / Favorable

Bad / Good

Negative / Positive

Attitude toward the corporation (Homer, 1995)

Negative / Positive

Unpleasant / Pleasant

Disagreeable / Agreeable

Worthless / Valuable

Bad / Good

Foolish / Wise

Unfavorable / Favorable

Dislike a lot / Like a lot

Useless / Useful

Discomfort (Elliot \& Devine, 1994)

The news I red makes me feel uncomfortable

The news I learned made me uneasy

The news I learned bothers me

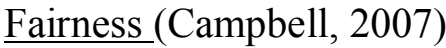

Unfair / Fair

Wrong / Right

Unreasonable / Reasonable

Perception of crisis seriousness

Personally, how serious do you think a company is involved in an environmental/workers maltreatment crisis? 


\section{$\underline{\text { Personal CSR relevance }}$}

Personally, how important do you think a company has a good reputation for its environmental culture/attention to the working conditions of their employees?

Purchase intention (Burton et al., 1999)

Would you be more likely or less likely to purchase the product, given the information shown?

Given the information shown, how probable is it that you would consider the purchase of the product?

How likely would you be to purchase the product, given the information shown?

Word of mouth (Arnett et al., 2003)

I "talk up" MSG to people I know

I bring up MSG in a positive way in conversations I have with friends and acquaintances

In social situations, I often speak favorably about MSG 


\section{Appendix B. Scenarios}

\section{Study 1}

\section{Manipulation of corporate reputation}

$\underline{\text { Reputation as "green company" }}$

MSG is an Indonesian producer of smartphones. The company was founded in 2005, and since its beginning has been known for its innovative management orientation around CSR. In Indonesia, the company is known for its distinct environmentalist culture, as evidenced by its many environmental certifications. The company always seeks to use eco-friendly materials for anything from packaging to product components, and all manufacturing processes are carried out in full compliance with environmental protection regulations.

Last year, the American magazine Forbes ranked MSG as the third greenest company in the world.

\section{$\underline{\text { Reputation as "best place to work" }}$}

MSG is an Indonesian producer of smartphones. The company was founded in 2005, and since its beginning has been known for its innovative management orientation around CSR. In Indonesia, it is known for its outstanding attention to employee working conditions. The company has always invested in continuous training programs and the creation of a favourable working climate in which each employee is given the opportunity to contribute to the company without pressure or stress. Working hours are flexible and intertwine with various recreational activities that also involve employees' families.

Last year, the American magazine Fortune ranked MSG as the world's third best place to work.

Manipulation of crisis triggering event

Crisis due to "pollution" 
During the past few weeks, while defining the details of its entry into Europe, MSG has suffered the most serious crisis in its history. The most important Indonesian television network showed how the company is not as "green" as it seems because it uses illegal landfills for the disposal of some of its most highly polluting smartphone components. Crisis due to "workers" exploitation"

During the past few weeks, while defining the details of its entry into Europe, MSG has suffered the most serious crisis in its history. The most important Indonesian television network showed how the company is not very careful about its employees' working conditions. In particular, the network has revealed that MSG controls a few small satellite firms that employ many noncontractual employees to meet the peaks of demand. They work exhausting hours with a salary equal to half the amount paid to MSG employees.

\section{Study 3}

Manipulation of company's post-crisis response Apology

Following the set of problems that occurred as a result of the crisis, MSG's CEO promptly, within a few hours of the negative event, circulated a press release apologising for the incident and assuming full responsibility for the negative events in the hope that everyone would accept the company's apology.

\section{Compensation}

Following the set of problems that occurred as a result of the crisis, MSG's CEO promptly, within a few hours of the negative event, circulated a press release informing the community that the company will pay each resident family living in the affected area a one-off contribution equivalent to the cost of one week's hotel stay. One week is the estimated amount of time required for mitigation. 


\section{References}

Arnett, D. B., German, S. D., \& Hunt, S. D. (2003). The Identity Salience Model of Relationship Marketing Success: The Case of Nonprofit Marketing. Journal of Marketing, 67(2), 89-105. http://doi.org/10.1509/jmkg.67.2.89.18614

Arpan, L. M., \& Roskos-Ewoldsen, D. R. (2005). Stealing thunder: Analysis of the effects of proactive disclosure of crisis information. Public Relations Review, 31(3), 425-433. http://doi.org/10.1016/j.pubrev.2005.05.003

Barclay, L. J., \& Skarlicki, D. P. (2008). Shifting perspectives: Helping victims recover from organizational justice violations. Research in Social Issues in Management, 6, $155-199$.

Benoit, W. L., \& Pang, A. (2008). Crisis communication and image repair discourse. In T. L. Hansen-Horn \& B. D. Neff (Eds.), Public relations: From theory to practice (pp. 243-261).

Brammer, S. J., \& Pavelin, S. (2006). Corporate reputation and social performance: The importance of fit. Journal of Management Studies, 43(3), 435-455. http://doi.org/10.1111/j.1467-6486.2006.00597.x

Bundy, J., Pfarrer, M. D., Short, C. E., \& Coombs, W. T. (2016). Crises and Crisis Management: Integration, Interpretation, and Research Development. Journal of Management, 43(6), 1661-1692. http://doi.org/10.1177/0149206316680030

Burgoon, J. K. (1993). Interpersonal expectations, expectancy violations, and emotional communication. Journal of Language and Social Psychology. http://doi.org/10.1177/0261927X93121003 
Burton, S., Garretson, J. A., \& Velliquette, A. M. (1999). Implications of Accurate Usage of Nutrition Facts Panel Information for Food Product Evaluations and Purchase Intentions. Journal of the Academy of Marketing Science, 27(4), 470480. http://doi.org/10.1177/0092070399274006

Campbell, M. C. (2007). "Says Who?!" How the source of price information and affect influence perceived price (un)fairness. Journal of Marketing Research, 44(2), 261271. http://doi.org/10.1509/jmkr.44.2.261

Caruana, A. (1997). Corporate reputation: concept and measurement. Journal of Product \& Brand Management, 6(2), 109-118. http://doi.org/10.1108/10610429710175646

Chun, R. (2005). Corporate reputation: Meaning and measurement. International Journal of Management Reviews, 7(2), 91-109. http://doi.org/10.1111/j.14682370.2005.00109.x

Claeys, A. S., \& Cauberghe, V. (2014). What makes crisis response strategies work? The impact of crisis involvement and message framing. Journal of Business Research, 67(2), 182-189. http://doi.org/10.1016/j.jbusres.2012.10.005

Claeys, A. S., Cauberghe, V., \& Vyncke, P. (2010). Restoring reputations in times of crisis: An experimental study of the Situational Crisis Communication Theory and the moderating effects of locus of control. Public Relations Review, 36(3), 256262. http://doi.org/10.1016/j.pubrev.2010.05.004

Coombs, W. T. (1995). Choosing the Right Words: The Development of Guidelines for the Selection of the "Appropriate" Crisis-Response Strategies. Management Communication Quarterly, 8(4), 447-476. 
http://doi.org/10.1177/0893318995008004003

Coombs, W. T. (2007). Protecting organization reputations during a crisis: The development and application of situational crisis communication theory. Corporate Reputation Review, 10(3), 163-176. http://doi.org/10.1057/palgrave.crr.1550049

Coombs, W. T. (2010). Parameters for Crisis Communication. In The Handbook of Crisis Communication (pp. 17-53). http://doi.org/10.1002/9781444314885.ch1

Coombs, W. T. (2016). Reflections on a meta-analysis: Crystallizing thinking about SCCT. Journal of Public Relations Research, 28(2), 120-122. http://doi.org/10.1080/1062726X.2016.1167479

Coombs, W. T., Frandsen, F., Holladay, S. J., \& Johansen, W. (2010). Why a concern for apologia and crisis communication? Corporate Communications: An International Journal, 15(4), 337-349. http://doi.org/10.1108/13563281011085466

Coombs, W. T., \& Holladay, S. J. (1996). Communication and Attributions in a Crisis: An Experimental Study in Crisis Communication. Journal of Public Relations Research, 8(4), 279-295. http://doi.org/10.1207/s1532754xjprr0804_04

Coombs, W. T., \& Holladay, S. J. (2002). Helping Crisis Managers Protect Reputational Assets: Initial Tests of the Situational Crisis Communication Theory. Management Communication Quarterly, 16(2), 165-186.

http://doi.org/10.1177/089331802237233

Coombs, W. T., \& Holladay, S. J. (2006). Unpacking the halo effect: reputation and crisis management. Journal of Communication Management, 10(2), 123-137. http://doi.org/10.1108/13632540610664698 
Coombs, W. T., \& Holladay, S. J. (2008). Comparing apology to equivalent crisis response strategies: Clarifying apology's role and value in crisis communication. Public Relations Review, 34(3), 252-257. http://doi.org/10.1016/j.pubrev.2008.04.001

Coombs, W. T., \& Holladay, S. J. (2012). Privileging an activist vs. a corporate view of public relations history in the U.S. Public Relations Review, 38(3), 347-353. http://doi.org/10.1016/j.pubrev.2011.11.010

Coombs, W. T., \& Holladay, S. J. (2015). CSR as crisis risk: expanding how we conceptualize the relationship. Corporate Communications: An International Journal, 20(2), 144-162. http://doi.org/10.1108/CCIJ-10-2013-0078

Coombs, W. T., Holladay, S. J., \& Claeys, A. S. (2016). Debunking the myth of denial's effectiveness in crisis communication: context matters. Journal of Communication Management, 20(4), 381-395. http://doi.org/10.1108/JCOM-062016-0042

Cooper, J., \& Fazio, R. H. (1984). A New Look at Dissonance Theory. Advances in Experimental Social Psychology, 17(C), 229-266. http://doi.org/10.1016/S00652601(08)60121-5

Dawar, N., \& Lei, J. (2009). Brand crises: The roles of brand familiarity and crisis relevance in determining the impact on brand evaluations. Journal of Business Research, 62(4), 509-516. http://doi.org/10.1016/j.jbusres.2008.02.001

De Cremer, D. (2010). To pay or to apologize? On the psychology of dealing with unfair offers in a dictator game. Journal of Economic Psychology, 31(6), 843-848. http://doi.org/10.1016/j.joep.2010.05.006 
Deephouse, D. L., \& Carter, S. M. (2005). An examination of differences between organizational legitimacy and organizational reputation. Journal of Management Studies. http://doi.org/10.1111/j.1467-6486.2005.00499.x

Desmet, P. T. M., de Cremer, D., \& van Dijk, E. (2010). On the Psychology of Financial Compensations to Restore Fairness Transgressions: When Intentions Determine Value. Journal of Business Ethics, 95(SUPPL. 1), 105-115. http://doi.org/10.1007/s10551-011-0791-3

Eisingerich, A. B., Rubera, G., Seifert, M., \& Bhardwaj, G. (2011). Doing Good and Doing Better despite Negative Information?: The Role of Corporate Social Responsibility in Consumer Resistance to Negative Information. Journal of Service Research, 14(1), 60-75. http://doi.org/10.1177/1094670510389164

Elliot, A. J., \& Devine, P. G. (1994). On the motivational nature of cognitive dissonance: Dissonance as psychological discomfort. Journal of Personality and Social Psychology, 67(3), 382-394. http://doi.org/10.1037/0022-3514.67.3.382

Festinger, L. (1957). A Theory of Cognitive Dissonance. Stanford University Press.

Fischer, E., \& Reuber, R. (2007). The good, the bad, and the unfamiliar: The challenges of reputation formation facing new firms. Entrepreneurship: Theory and Practice, 31(1), 53-75. http://doi.org/10.1111/j.1540-6520.2007.00163.x

Fredricksen, C. (2012). College Students Adopt Mobile across the Board. Retrieved from http://www.emarketer.com/newsroom/index.php/college-students-adoptmobile-board/

Gao, H., Knight, J. G., Zhang, H., Mather, D., \& Tan, L. P. (2012). Consumer 
scapegoating during a systemic product-harm crisis. Journal of Marketing Management, 28(11-12), 1270-1290.

http://doi.org/10.1080/0267257X.2011.645859

Gistri, G., Corciolani, M., \& Pace, S. (2018). The interaction effect between brand identification and personal crisis relevance on consumers' emotional reactions to a fashion brand crisis. Journal of Global Fashion Marketing, 9(3), 252-269.

Grappi, S., \& Romani, S. (2015). Company Post-Crisis Communication Strategies and the Psychological Mechanism Underlying Consumer Reactions. Journal of Public Relations Research, 27(1), 22-45. http://doi.org/10.1080/1062726X.2014.924839

Grund, N. E., \& Fombrun, C. J. (1996). Reputation: Realizing value from the corporate image. Academy of Management Perspectives, 10(1), 99-101. http://doi.org/10.5465/AME.1996.9603293245

Haesevoets, T., Reinders Folmer, C., De Cremer, D., \& Van Hiel, A. (2013). Money isn't all that matters: The use of financial compensation and apologies to preserve relationships in the aftermath of distributive harm. Journal of Economic Psychology, 35, 95-107. http://doi.org/10.1016/j.joep.2013.02.003

Ham, C. D., \& Kim, J. (2017). The Role of CSR in Crises: Integration of Situational Crisis Communication Theory and the Persuasion Knowledge Model. Journal of Business Ethics, 1-20. http://doi.org/10.1007/s10551-017-3706-0

Hayes, A. (2013). Introduction to mediation, moderation, and conditional process analysis. New York, NY: Guilford. http://doi.org/978-1-60918-230-4

Heckler, S. E., \& Childers, T. L. (1992). The Role of Expectancy and Relevancy in 
Memory for Verbal and Visual Information: What is Incongruency? Journal of Consumer Research, 18(4), 475. http://doi.org/10.1086/209275

Hetze, K. (2016). Effects on the (CSR) Reputation: CSR Reporting Discussed in the Light of Signalling and Stakeholder Perception Theories. Corporate Reputation Review, 19(3), 281-296. http://doi.org/10.1057/s41299-016-0002-3

Hinojosa, A. S., Gardner, W. L., Walker, H. J., Cogliser, C., \& Gullifor, D. (2017). A Review of Cognitive Dissonance Theory in Management Research. Journal of Management, 43(1), 170-199. http://doi.org/10.1177/0149206316668236

Homer, P. M. (1995). Ad size as an indicator of perceived advertising costs and effort: The effects on memory and perceptions. Journal of Advertising, 24(4), 1-12. http://doi.org/10.1080/00913367.1995.10673485

Ingenbleek, P. T. M., Meulenberg, M. T. G., \& Van Trijp, H. C. M. (2015). Buyer social responsibility: a general concept and its implications for marketing management. Journal of Marketing Management, 31(13-14), 1428-1448. http://doi.org/10.1080/0267257X.2015.1058848

Janssen, C., Sen, S., \& Bhattacharya, C. B. (2015). Corporate crises in the age of corporate social responsibility. Business Horizons, 58(2), 183-192. http://doi.org/10.1016/j.bushor.2014.11.002

Jeon, J. O., \& Baeck, S. (2016). What Drives Consumer's Responses to Brand Crisis? The Moderating Roles of Brand associations and Brand-Customer Relationship Strength. Journal of Product \& Brand Management, 25(6), 550-567. http://doi.org/10.1002/elan. 
Joireman, J., Smith, D., Liu, R. L., \& Arthurs, J. (2015). It's All Good: Corporate Social Responsibility Reduces Negative and Promotes Positive Responses to Service Failures Among Value-Aligned Customers. Journal of Public Policy \& Marketing, 34(1), 32-49. http://doi.org/10.1509/jppm.13.065

Jones, B., Temperley, J., \& Lima, A. (2009). Corporate reputation in the era of Web 2.0: the case of Primark. Journal of Marketing Management, 25(9-10), 927-939. http://doi.org/10.1362/026725709X479309

Kahneman, D., \& Tversky, A. (1979). Prospect Theory: An Analysis of Decision under Risk. Econometrica: Journal of the Econometric Society, 47(3), 263-291. http://doi.org/10.1111/j.1536-7150.2011.00774.x

Kang, C., Germann, F., \& Grewal, R. (2016). Washing Away Your Sins? Corporate Social Responsibility, Corporate Social Irresponsibility, and Firm Performance. Journal of Marketing, 80(2), 59-79. http://doi.org/10.1509/jm.15.0324

Kantor, J., \& Streitfeld, D. (2015). Inside Amazon: Wrestling Big Ideas in a Bruising Workplace. The New York Times. New York. Retrieved from https://www.nytimes.com/2015/08/16/technology/inside-amazon-wrestling-bigideas-in-a-bruising-workplace.html

Khan, J. (2011). Validation in marketing experiments revisited. Journal of Business Research, 64(7), 687-692. http://doi.org/10.1016/j.jbusres.2010.08.009

Klein, J., \& Dawar, N. (2004). Corporate social responsibility and consumers' attributions and brand evaluations in a product-harm crisis. International Journal of Research in Marketing, 21(3), 203-217. http://doi.org/10.1016/j.ijresmar.2003.12.003 
Lee, Y. H., \& Mason, C. (1999). Responses to Information Incongruency in Advertising: The Role of Expectancy, Relevancy, and Humor. Journal of Consumer Research, 26(2), 156-169. http://doi.org/10.1086/209557

Liao, H. (2007). Do it right this time: the role of employee service recovery performance in customer-perceived justice and customer loyalty after service failures. The Journal of Applied Psychology, 92(2), 475-89.

http://doi.org/10.1037/0021-9010.92.2.475

Maille, V., \& Fleck, N. (2011). Perceived Congruence and Incongruence: Toward a Clarification of the Concept, its Formation and Measure. Recherche et Applications En Marketing, 26(2), 77-113. http://doi.org/10.1177/205157071102600204

Newman, L. S., \& Kraynak, L. R. (2013). the Ambiguity of a Transgression and the Type of Apology Influence Immediate Reactions. Social Behavior \& Personality: An International Journal, 41(1), 31-45. http://doi.org/10.2224/sbp.2013.41.1.31

Nielsen. (2015). The Sustainability Imperative. Global Sustainability Report. Retrieved from http://www.nielsen.com/us/en/insights/reports/2015/the-sustainabilityimperative.html

Perdue, B. C., \& Summers, J. O. (1986). Checking the Success of Manipulations in Marketing Experiments. Journal of Marketing Research, 23(4), 317. http://doi.org/10.2307/3151807

PricewaterhouseCoopers. (2016). Redefining business success in a changing world. 19th Annual Global CEO Survey. Retrieved from http://www.pwc.com/gx/en/ceosurvey/2016/landing-page/pwc-19th-annual-global-ceo-survey.pdf 
Rao, H. (1994). The Social Construction of Reputation: Certification Contests, Legitimation, and the Survival of Organizations in the American Automobile Industry: 1895-1912. Strategic Management Journal, 15(1 S), 29-44. http://doi.org/10.1002/smj.4250150904

Reputation Institute. (2015). CSR Reputation Leaders in the US. Retrieved from https://www.reputationinstitute.com/sites/default/files/pdfs/2015-US-CSRRepTrak.pdf

Reputation Institute. (2016). CSR RepTrak® 100. http://doi.org/10.1021/jo00050a048

Rhee, M., \& Haunschild, P. R. (2006). The Liability of Good Reputation: A Study of Product Recalls in the U.S. Automobile Industry. Organization Science, 17(1), 101-117. http://doi.org/10.1287/orsc.1050.0175

Rindova, V. P., Williamson, I. O., Petkova, A. P., \& Sever, J. M. (2005). Being good or being known: An empirical examination of the dimensions, antecedents, and consequences of organizational reputation. Academy of Management Journal. http://doi.org/10.5465/AMJ.2005.19573108

Rokka, J., Karlsson, K., \& Tienari, J. (2014). Balancing acts: Managing employees and reputation in social media. Journal of Marketing Management, 30(7-8), 802-827. http://doi.org/10.1080/0267257X.2013.813577

Roschk, H., \& Kaiser, S. (2013). The nature of an apology: An experimental study on how to apologize after a service failure. Marketing Letters, 24(3), 293-309. http://doi.org/10.1007/s11002-012-9218-x

Smith, J. (2013). The Companies With the Best CSR Reputations. Retrieved from 
https://www.forbes.com/sites/jacquelynsmith/2013/10/02/the-companies-with-thebest-csr-reputations-2/

Sohn, Y. J., \& Lariscy, R. W. (2015). A “buffer" or “boomerang?"-The role of corporate reputation in bad times. Communication Research. http://doi.org/10.1177/0093650212466891

Spangenberg, E. R., Sprott, D. E., Grohmann, B., \& Smith, R. J. (2003). MassCommunicated Prediction Requests: Practical Applicaton and a Cognitive Dissonance Explanation for Self-Prophecy. Journal of Marketing, 67(3), 47-62. http://doi.org/10.1509/jmkg.67.3.47.18659

Srivoravilai, N., Melewar, T. C., Liu, M. J., \& Yannopoulou, N. (2011). Value marketing through corporate reputation: An empirical investigation of Thai hospitals. Journal of Marketing Management, 27(3-4), 243-268. http://doi.org/10.1080/0267257X.2011.545676

Tsarenko, Y., \& Tojib, D. (2015). Consumers' forgiveness after brand transgression: The effect of the firm's corporate social responsibility and response. Journal of Marketing Management, 31(17-18), 1851-1877. http://doi.org/10.1080/0267257X.2015.1069373

Vanhamme, J., \& Grobben, B. (2009). “Too good to be true!” The Effectiveness of CSR history in countering negative publicity. Journal of Business Ethics, 85(2), 273283. http://doi.org/10.1007/s10551-008-9731-2

Vanhamme, J., Swaen, V., Berens, G., \& Janssen, C. (2015). Playing with fire: aggravating and buffering effects of ex ante CSR communication campaigns for companies facing allegations of social irresponsibility. Marketing Letters, 26(4), 
565-578. http://doi.org/10.1007/s11002-014-9290-5

Varadarajan, P. R., \& Menon, A. (1988). Cause-Related Marketing: A Coalignment of Marketing Strategy and Corporate Philanthropy. Journal of Marketing, 52(3), 58. http://doi.org/10.2307/1251450

Wagner, T., Lutz, R. J., \& Weitz, B. A. (2009). Corporate Hypocrisy: Overcoming the Threat of Inconsistent Corporate Social Responsibility Perceptions. Journal of Marketing, 73(6), 77-91. http://doi.org/10.1509/jmkg.73.6.77

Weiner, B. (1985). An attributional theory of achievement motivation and emotion. Psychological Review, 92(4), 548-573. http://doi.org/10.1037/0033-295X.92.4.548

Yannopoulou, N., Koronis, E., \& Elliott, R. (2011). Media amplification of a brand crisis and its affect on brand trust. Journal of Marketing Management. http://doi.org/10.1080/0267257X.2010.498141

Zavyalova, A., Pfarrer, M. D., Reger, R. K., \& Hubbard, T. D. (2016). Reputation as a benefit and a burden? How stakeholders' organizational identification affects the role of reputation following a negative event. Academy of Management Journal, 59(1), 253-276. http://doi.org/10.5465/amj.2013.0611

Zhao, X., Lynch Jr., J. G., \& Chen, Q. (2010). Reconsidering Baron and Kenny: Myths and Truths about Mediation Analysis. Journal of Consumer Research, 37(2), 197206. http://doi.org/10.1086/651257

i See also Kang et al. (2016) about the effects of CSR on firms' performances. 
${ }^{\text {ii }}$ See Kantor and Streitfeld (2015) for details on the New York Times investigation of the working conditions at Amazon.

iii These variables have been extensively used in the literature on consumers' reactions to crises (Coombs \& Holladay, 2006; Grappi \& Romani, 2015; Ham \& Kim, 2017).

${ }^{\text {iv }}$ This article does not contain any studies with animals performed by any of the authors. All procedures performed in studies involving human participants were in accordance with the ethical standards of the institutional and/or national research committee and with the 1964 Helsinki declaration and its later amendments or comparable ethical standards. Informed consent was obtained from all individual participants included in the study.

${ }^{\mathrm{v}}$ For further details about experimental manipulations, see appendix B.

vi We chose this country because in a separate pretest with 40 students from the same main study population (average age 22 years; 19 males, 21 females), the students answered Indonesia (45\%), followed by China (40\%) and others (15\%), to the question "Which country is the largest smartphone manufacturer?”.

vii We gave participants a newspaper article on an unrelated topic (business innovation) to read as filler. The aim was to reduce demand bias by obscuring the connection between the experiment and the measurement (Khan, 2011).

viii For further details, see appendix A.

ix We manipulated only the dimension of the CSR crisis, while we kept constant the good corporate reputation scenario.

${ }^{x}$ Importantly, we also demonstrated that the effect of CPI is independent from the CSR dimension of corporate reputation. That is, in cases of dimensional matches (i.e., high CPI), we found the same effects in terms of consumer reactions to the crisis, independent of the dimension of corporate reputation ("green company" or "best place to work"). The same outcome occurred in cases of low CPI. We thus concluded that the match versus mismatch rationale in differentiating consumer reactions was effective. 